\title{
Elīna Ligere
}

\section{AORTAS KOARKTĀCIJAS KLĪNISKIE, EHOKARDIOGRĀFISKIE UN BIOMEHĀNISKIE ASPEKTI AGRINNA VECUMA BËRNIEM LATVIJĀ}

Promocijas darba kopsavilkums medicīnas doktora zinātniskā grāda iegūšanai Specialitāte - bērnu kardioloǵija

Rīga, 2013 


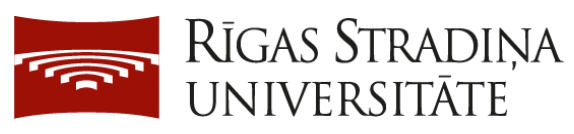

Elīna Ligere

\section{AORTAS KOARKTĀCIJAS KLĪNISKIE, EHOKARDIOGRĀFISKIE UN BIOMEHĀNISKIE ASPEKTI AGRĪNA VECUMA BĒRNIEM LATVIJĀ}

Promocijas darba kopsavilkums

Specialitāte - bērnu kardiologija

Rīga, 2013 
Promocijas darbs izstrādāts Bērnu klīniskās universitātes slimnīcas Bērnu kardiolog̣ijas un kardioķirurg̣ijas klīnikā.

Biomehāniskie eksperimenti veikti Rīgas Stradiṇa universitātes Biomehānikas laboratorijā.

Darba zinātniskie vadītāji:

Dr. habil. med., profesors Aris Lācis, Bērnu klīniskā universitātes slimnīca, Bērnu kardiolog̣ijas un kardioķirurğijas klīnika

Dr. habil. ing. sc., profesors, LZA kor. loc. Vladimirs Kasjanovs, Rīgas Stradiṇa universitāte, Biomehānikas laboratorija

Oficiālie recenzenti:

Dr. med., profesors Oskars Kalējs (Rīgas Stradiņa universitāte)

Dr. med., vadošais pētnieks Indulis Kukulis (Latvijas Universitāte)

Dr. med., Vita Zīdere (Lielbritānija)

Promocijas darba aizstāvēšana notiks 2013. gada 26. novembrī plkst. 13.00 Rīgas Stradiṇa universitātes Medicīnas promocijas padomes atklātā sēdē Rīgā, Dzirciema ielā 16, Senāta zālē.

Ar promocijas darbu var iepazīties RSU bibliotēkā un RSU mājaslapā: www.rsu.lv

Promocijas darbs veikts ar Eiropas Sociālā fonda projekta "Atbalsts doktorantiem studiju programmas apguvei un zinātniskā grāda ieguvei Rīgas Stradiṇa universitātē” finansiālu atbalstu.
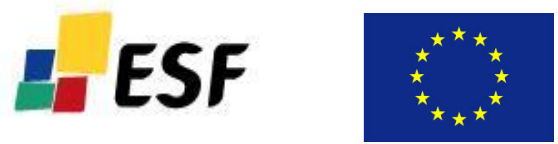

Promocijas padomes sekretāre:

Dr. habil. med., Līga Aberberga-Augškalne 


\section{SATURS}

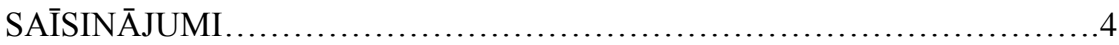

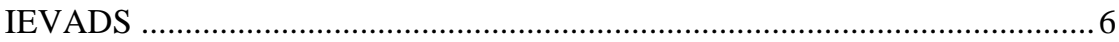

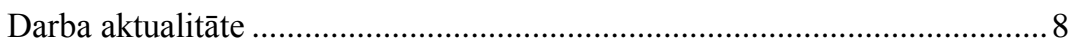

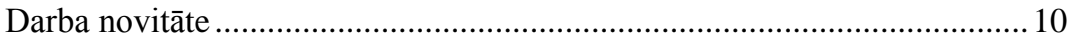

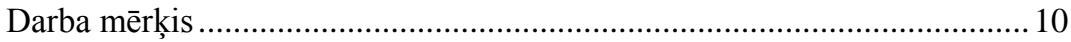

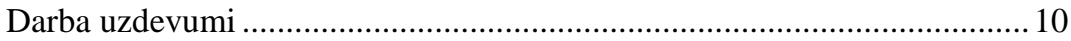

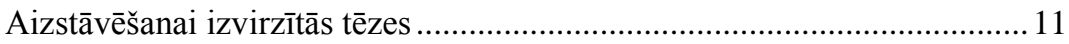

1.1. Pētījuma perioda izvēles pamatojums ................................................... 12

1.2. Aortas koarktācijas klīniskās pētījuma grupas raksturojums ............... 13

1.3. Pētījuma pacientu ehokardiogrāfiskā izmeklēšana................................. 17

1.4. Aortas loka biomehāniskā pētījuma materiāls un metodes ................... 19

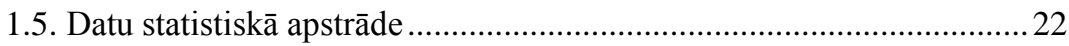

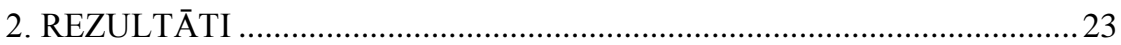

2.1. Aortas koarktācijas prevalence jaundzimušajiem Latvijā

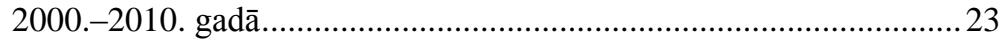

2.2. Aortas koarktācijas kā no arteriāla vada atkarīgas sirdskaites atpazīstamība Latvijā 2005.-2010. gadā.............................................23

2.3. Koarktācijas ķirurğiskās ārstēšanas rezultāti jaundzimušajiem un zīdainiem Latvijā 2000.-2010. gadā.................................................26

2.4. Ehokardiogrāfisks novērtējums pacientiem ar agrīnā vecumā korig̣ētu koarktāciju Latvijā 2000.-2010. gadā ..................................33

2.5. Aortas loka biomehāniskās īpašības jaundzimušajiem un zīdaiņiem dažādu AoCo ķirurğiskai ārstēšanai izmantotu

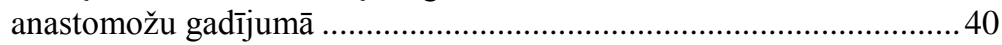

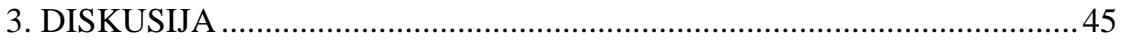

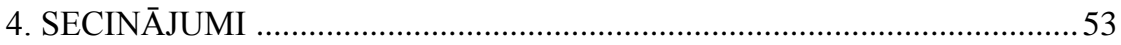

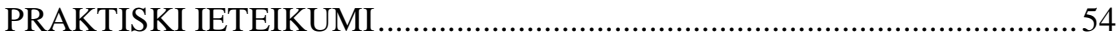

PUBLIKĀCIJAS UN ZIN̦OJUMI PAR PĒTĪJUMA TĒMU ...........................56 


\section{SAĪSINĀJUMI}

AGG - anastomoze gals-galā

Ao - aorta

AoCo - aortas koarktācija

AoreCo - aortas rekoarktācija

AoS - aortas stenoze

AS - arteriālais asinsspiediens

ASD $\quad-$ atriju starpsienas defekts

AVSD - atrioventrikulārs septāls defekts

BKUS - Bērnu klīniskā universitātes slimnīca

CWD - nepārtraukta viļ̣na doplerogrāfija

DILV - dubultieplūšana kreisajā ventrikulā

DORV - dubultatiešana no labā ventrikula

EHOKG - ehokardiogrāfija

EF - izsviedes frakcija

FS - saraušanās frakcija

HLHS - kreisās sirds hipoplāzijas sindroms

KVM - kardiovaskulāra mazspēja

IVSd - ventrikulu starpsiena diastolē

IZA - ielāps ar kreisās zematslēgas artērijas lēveru

LV - kreisais ventrikuls

LVEDD - kreisā ventrikula diametrs diastolē

LVESD - kreisā ventrikula diametrs sistolē

LVM - kreisā ventrikula masa

LVMi - kreisā ventrikula masas indekss

LVPWd - kreisā ventrikula mugurējā sieniņa diastolē

MAT - maǵistrālo asinsvadu transpozīcija

MS - mitrālā vārstuḷa stenoze

PAGG - pagarināta anastomoze gals-galā

PBA - primāra angioplastija

PDA - atvērts arteriāls vads

PgE1 - Prostoglandīns E1

Pg maks.- maksimālais spiediena gradients

PH - pulmonāla hipertensija

PS - plaušu artērijas stenoze

PWD - pulsa viḷna doplerogrāfijāa 
PWD D - minimālais plūsmas ātrums diastolē PWD

PWD S - maksimālais plūsmas ātrums sistolē PWD

PWD S/D - sistoliskas/diastoliskas plūsmas attiecība PWD

TI - ticamības intervāls

$\mathrm{X}^{2} \quad-$ hī kvadrāts

VCC - iedzimta sirdskaite (vitium cordis congenita)

VSD - ventrikulu starpsienas defekts 


\section{IEVADS}

Iedzimtu sirdskaiti novēro 8-12 no 1000 dzīvi dzimušiem bērniem. Tā ir viena no biežākajām un nopietnākajām iedzimtajām anomālijām. Apmēram ceturtajai dạ̧ai bērnu ar iedzimtu sirdskaiti tā uzskatāma par kritisku, kurai nepieciešama ķirurğiska vai transvazāla korekcija jau pirmajā dzīves gadā (Chang et al., 2008; Hoffman et Kaplan, 2002).

Aortas koarktācija ir descendējošās aortas sašaurinājums arteriāla vada pievienošanās vietā, parasti distāli no kreisās zematslēgas artērijas atzarošanās. Pēc literatūras datiem, tās incidence populācijā ir $36(29-49) / 100000$ jaundzimušo (Park, 2008; Dolk et al., 2010), un tā veido 6-10\% no visām iedzimtajām sirdskaitēm. Pēc Eiropas iedzimtu anomāliju uzraudzības sistēmas datiem (European surveillance of congenital anomalies), AoCo prevalence laika posmā no 2005. līdz 2009. gadam bija 2,49-3,01 no 10000 dzīvi dzimušajiem. Aptuveni 64\% gadījumu jaundzimušajiem ar aortas koarktāciju tā manifestējas kā vadošā sirdskaite jau drīz pēc piedzimšanas, kuras gadījumā nepieciešama agrīna sirdskaites korekcija (Samanek et Voriskova, 1999).

Literatūrā publicētajos pētījumos par laikus nekonstatētām iedzimtajām sirdskaitēm kā jaundzimušo nāves cēloni (Chang et al., 2008; Massin et Dessy, 2006) konstatēts, ka trīs ceturtdalāàm pacientu šajā grupā ir infantila koarktācija un hipoplastiskas kreisās sirds sindroms. Pētījumi parāda, ka pusei jaundzimušo, kuri atstājuši dzemdību iestādi ar neatklātu iedzimtu sirdskaiti, bija aortas koarktācija (Wren et al., 2008). Daudzi jaundzimušie ar smagām iedzimtām sirdskaitēm tiek izrakstīti no dzemdību nodaļas bez diagnosticētas sirds patologijas, neraugoties uz arvien plašāk pieejamām jaunākajām diagnostikas metodēm (Mahle et al., 2009; Riede et al., 2010). Smagas fizioloǵiskas izmaiņas jaundzimušajam kā sekas iepriekš nediagnosticētai iedzimtai sirdskaitei novēro 1 no 15000 līdz 1 no 26000 dzīvi 
dzimušo (Schulz et al., 2008). Problēmu aktualizē arī tendence jaundzimušos agrīni izrakstīt mājās pēc piedzimšanas, kā arī dažādas izmaiņas jaundzimušo aprūpē. Biežāk vēlīni tiek konstatētas sirdskaites, kas nosaka no arteriāla vada atkarīgu sistēmisku cirkulāciju pretstatā no arteriāla vada atkarīgai plaušu asinsritei, kas manifestēsies ar cianozi (Mellander et Sunnegardh, 2006). Klīnikā ikdienā radies priekšstats, ka no arteriālā vada atkarīgas iedzimtas sirdskaites joprojām uzskatāmas par nozīmīgu cēloni jaundzimušo saslimstībai un mirstībai mūsu valstī, tāpēc problēma ir izpētes vērta.

Latvijā nav iedzimtu sirdskaišu reǵistra. Datus par sirdskaites epidemiolog̣iju jaundzimušajiem mūsu valstī var iegūt, tikai apkopojot tādus avotus kā Bērnu klīniskās universitātes slimnīcas (BKUS) Bērnu kardiologijas un kardioķirurğijas klīnikā pirmreizēji diagnosticētu sirdskaišu datubāze, operāciju un angiogrāfiju reǵistrācijas žurnālu un BKUS Bērnu patoloǵiju biroja dati. Situāciju nedaudz atvieglo fakts, ka bērni ar iedzimtajām sirdskaitēm Latvijā tiek ārstēti tikai BKUS, tādējādi dati ir attiecināmi uz populāciju valstī.

Pēdējās desmitgades laikā būtiski uzlabojušās iedzimtu sirdskaišu diagnosticēšanas un ārstēšanas iespējas pasaulē (Kugler et al., 2009; Tchervenkov et al., 2008) un Latvijā. Arvien nozīmīgāka kḷūst preoperatīvas saslimstības un mirstības novēršana. N̦emot vērā atšķirīgu sirdskaites anatomiju koarktācijas gadījumā un iespējamās pavadošās patologijas, vienotas universālas ārstēšanas metodes nav. Kopš 20. gadsimta 60. gadiem uzsākta un attīstījusies sekmīga aortas koarktācijas ķirurğiska ārstēšana (Brown et al., 2009; Burch et al., 2009; Hager et al., 2009; Jonas, 2004; Kaushal et al., 2009; Karamlau et al., 2009; Pandey et al., 2006; Sudarshan et al., 2006; Thomson et al., 2006). 20. gadsimta 80. gados aortas koarktācijas korekcijai pasaulē sāka lietot balonangioplastiju, kuras ilgtermiņa rezultāti agrīnā vecuma grupā primāru koarktāciju gadījumā ir diskutabli un tiek pretrunīgi vērtēti (Fiore et al., 2005; Fruh et al., 2011; Peres et al., 2010; Walhout et al., 2004). Lai 
spriestu par pareizāko taktiku aortas koarktācijas gadījumā jaundzimušajiem, nepieciešams apkopot un analizēt literatūras datus un līdzšinējo klīnisko pieredzi.

Aortas koarktācijas gadījumā pastāv rekoarktācijas, arteriālas hipertensijas, aortas aneirismu veidošanās un aortas disekcijas risks, kaut arī var būt veikta adekvāta ķirurǵiska korekcija agrīnā vecumā (Beekman, 2008; Rosenthal, 2005).

Literatūrā ir salīdzinoši maz datu par aortas loka biomehāniskajām īpašībām jaundzimušajiem un zīdaiņiem. Atrodami dati par aortas biomehāniskajām īpašībām eksperimentālajiem dzīvniekiem (Huang et al., 2006; Kassab, 2006; Manon et al., 2012). Cilvēka aortas pētījumos vairāk aprakstīti novecošanās procesi, aterosklerozes radītas biomehāniskās izmaiņas, aneirismu veidošanās, tomēr informācija par aortas biomehāniskajām īpašībām jauniem indivīdiem ir ierobežota (Guinea et al., 2010). Attīstoties ultrasonogrāfijas tehnologijām, arvien vairāk tiek veikti in vivo eksperimenti in situ apstākḷos, galvenokārt pētījumos ar dzīvniekiem. Lai detalizēti pētītu artēriju sieniņas biomehāniku, jāveic pētījumi in vitro (Hayash et al., 2001).

\section{Darba aktualitāte}

Iedzimtas anomālijas ir viens no galvenajiem jaundzimušo nāves cēloṇiem attīstītajās valstīs (Chang et al., 2008; Mahle et al., 2009). Latvijā joprojām ir augsti zīdaiņu mirstības rādītāji: 7,8/1000 2005. gadā un 5,7/1000 2010. gadā (zīdaiņu mirstība līdz 1 gada vecumam gadā no 1000 dzìvi dzimušajiem) (LR Centrālās statistikas pārvaldes dati). Savlaicīga iedzimto sirdskaišu atpazīšana varētu mazināt šos rādītājus, īpaši gadījumos, kad 
iespējama veiksmīga patoloǵijas ķirurǵiska ārstēšana. Nav pieejami dati par aortas koarktāciju kā jaundzimušo saslimstības un mirstības cēloni Latvijā.

Attīstoties diagnosticēšanas un ārstēšanas iespējām bērnu kardioloǵijā, arvien palielinās diagnosticēto iedzimto sirdskaišu un izdzīvojušo pacientu skaits pēc veiksmīgas sirdskaites ķirurǵiskas korekcijas jaundzimušā un zīdaiņa vecumā. Šie pacienti turpmāk veidos pieaugušu iedzimtu sirdskaišu pacientu grupu jeb GUCH grupu (grown up congenital heart diseases).

Darbā analizēta aortas koarktācija, kas aprakstīta kā septītā biežākā sirdskaite. Tādējādi pat valstī ar mazu populāciju un zemiem dzimstības rādītājiem ikvienam pediatram, ehokardiogrāfijas speciālistam un ǵimenes ārstam pastāv iespēja saskarties ar pacientu, kuram ir nediagnosticēta vai arī iepriekš operēta šāda sirds patologija. Tāpēc ir nepieciešamas papildu zināšanas šādu pacientu izmeklēšanā, ārstēšanā un aprūpē, turklāt ir svarīgi izvērtēt ķirurğiskās ārstēšanas vēlīnos rezultātus saistībā ar lietoto ķirurǵiskās ārstēšanas metodi.

Mūsdienās ehokardiogrāfiska izmeklēšana kalpo kā neinvazīva pamatmetode bērnu kardiovaskulārās sistēmas izvērtēšanai pirms un pēc ķirurğiskas ārstēšanas. Būtiski ir veikt ehokardiogrāfiskās atrades analīzi pacientiem ar konkrētu iedzimtu sirdskaiti pirms un pēc tās primāras ķirurğiskas korekcijas, kā arī novērot bērnus dinamikā, kas sekmē savlaicīgu komplikāciju atpazī̌̌anu.

Biomehānisko īpašību izpēte eksperimenta apstākḷıs ļauj skaidrāk izprast dažādu lietoto aortas koarktācijas korekcijas metožu ietekmi uz asinsvada biomehāniskajām īpašībām, kā arī sniedz priekšstatu par šo fiziolog̣isko izmaiņu biomehāniskajiem cēloṇiem un artērijas sieniņas iespējamajām izmaiņām balonangioplastijas laikā.

Līdz šim Latvijā publicēti tikai daži pētījumi, kuros analizētas sirds patoloǵijas bērniem mūsu valstī. 


\section{Darba novitāte}

1. Pētîjumā iegūtie rezultāti sniedz jaunu informāciju par aortas koarktācijas prevalenci jaundzimušajiem un zīdaiņiem Latvijā laika posmā no 2000. līdz 2010. gadam.

2. Pirmo reizi Latvijā analizēti mirstību un saslimstību ietekmējoši faktori pacientiem, kuriem koarktācija diagnosticēta un ārstēta jaundzimušā un zīdaiņa vecumā Latvijā kopš 2000. gada ar novērojuma periodu līdz 2011. gada beigām.

3. Pētījums atspoguḷo ehokardiogrāfisko atradi diagnozes noteikšanas brīdī, pēcoperācijas periodā, novērojot pacientu dinamikā, rekoarktācijas gadījumā, kā arī vidēji ilgā termiņā pēc sirdskaites korekcijas pacientiem ar aortas koarktāciju jaundzimušo un zīdaiṇu vecumā Latvijā pēdējā desmitgadē.

4. Darbā veikts iepriekš neaprakstīts jaundzimušā un zīdaiņa natīvās un ķirurg̣iski korig̣êtas aortas biomehānisks pētījums.

\section{Darba mērķis}

Noskaidrot aortas koarktācijas ārstēšanas optimālās iespējas agrīna vecuma bērniem Latvijā.

\section{Darba uzdevumi}

1. Pētīt un analizēt aortas koarktācijas prevalenci jaundzimušajiem un zīdaiņiem Latvijā laika posmā no 2000. līdz 2010. gadam. 
2. Novērtēt komplikācijas un letalitāti ietekmējošos faktorus agrīna vecuma bērniem ar aortas koarktāciju.

3. Pilnveidot ehokardiogrāfijas protokolu izmeklēšanai bērniem ar koarktāciju pirms un pēc tās ķirurgiskas korekcijas un analizēt ehokardiogrāfijas atradi pacientiem, kuriem aortas koarktācija diagnosticēta un ārstēta pirmajā dzīves gadā.

4. Izvērtēt vēlīnos rezultātus pacientiem, kuriem aortas koarktācijas korekcija veikta jaundzimušā un zīdaiņa vecumā.

5. Veikt biomehāniskus pētījumus, salīdzināt dažādas aortas koarktācijas korekcijas anastomožu īpašības bērniem, izmantojot autopsijas materiālu.

6. Izstrādāt praktiskus ieteikumus aortas koarktācijas diagnosticēšanā un ārstēšanā agrīna vecuma bērniem.

\section{Aizstāvēšanai izvirz̄îās tēzes}

1. Aortas koarktācijas prevalence Latvijā neatšķiras no citu Eiropas valstu datiem, tomēr saistībā ar pavadošu intrakardiālu patologiiju aortas koarktācija joprojām uzskatāma par būtisku mirstības cēloni agrīna vecuma bērniem.

2. Ķirurgíski korig̣ētas aortas biomehāniskās īpašības ir atškirīgas atkarībā no ķirurğiskās ārstēšanas metodes.

3. Aortas koarktācija uzskatāma par kompleksu kardiovaskulāru sindromu, kas nosaka nepieciešamību regulāri un sistemātiski izmeklēt pacientu visu mūžu sakarā ar multiplu komplikāciju attīstības risku (aortas rekoarktācija, arteriāla hipertensija, aortas aneirismas veidošanās). 


\section{MATERIĀLS UN METODES}

Darbs izstrādāts BKUS Bērnu kardiologijas un kardioķirurğijas klīnikā laika posmā no 2008. līdz 2012. gadam. Saņemta BKUS Ētikas komisijas aţ̦auja pētījuma veikšanai. Pētījums sastāv no biomehāniskās un klīniskās daḷām. Biomehāniskie eksperimenti veikti Rīgas Stradina universitātes Biomehānikas laboratorijā.

\subsection{Pētījuma perioda izvēles pamatojums}

Pirms pētījuma uzsākšanas analizētas visas publikācijas par aortas koarktācijas (AoCo) ārstēšanu jaundzimušajiem un zīdaiņiem Latvijā (Lācis un Volkolakovs, 1994; Volkolakovs un Lācis, 1987), BKUS Bērnu kardiologijas un kardioķirurǵijas klīnikas operāciju reǵistrācijas žurnāla dati (kopš 1996. gada) un P. Stradiṇa KUS Sirds ķirurǵ̣ijas klīnikas operāciju reǵistrācijas žurnāla dati (1984.-1994. gads) par AoCo ķirurğisku korekciju bērniem vecumā līdz 1 gadam. AoCo korekcija bērniem Latvijā tiek veikta kopš 1964. gada, sākotnēji P. Stradiṇa KUS. Nodibinoties Bērnu kardiolog̣ijas centram 1994. gadā (operācijas sāktas 1997. gadā), kas 2006. gadā kḷuva par BKUS Bērnu kardiologiijas un kardioķirurğijas klīniku, AoCo ķirurğiska korekcija bērniem Latvijā tiek veikta tikai BKUS. Konstatēts, ka laika posmā no 1964. līdz 1985. gadam P. Stradiņa KUS operēti 32 bērni ar AoCo līdz 1 gada vecumam (no tiem 2 bērni līdz 3 mēnešu vecumam), kopējā letalitāte 25\% (Volkolakovs un Lācis, 1987). Pēc operāciju reǵistrācijas datiem, laika posmā no 1984. gada līdz 1994. gadam P. Stradiṇa KUS AoCo ķirurǵgiski korig̣ēta 30 bērniem līdz 1 gada vecumam, un tikai vienam bērnam jaundzimušo vecumā. 
Pēc BKUS operāciju reǵistrācijas datiem, laika posmā no 1997. līdz 1999. gadam AoCo korekcija vecumā līdz 1 gadam veikta 9 bērniem (8 zìdaiṇu, 1 jaundzimušo vecumā). N̦emot vērā niecīgo jaundzimušo īpatsvaru laika posmā līdz 2000. gadam, kas neļauj pilnvērtīgi pêtīt AoCo kā potenciāli no arteriāla vada atkarīgu patolog̣iju jaundzimušajiem un zīdaiņiem, aprakstošam pētījumam izvēlēts laika posms no 2000. gada 1.janvāra līdz 2010. gada 31. decembrim.

\subsection{Aortas koarktācijas klīniskās pētījuma grupas raksturojums}

Lai pētītu AoCo prevalenci jaundzimušajiem Latvijā, no BKUS Bērnu kardiolog̣ijas un kardioķirurg̣ijas klīnikas operāciju reǵistrācijas žurnāla atlasīti visi 100 pacienti, kam AoCo korekcija veikta laika posmā no 2000. gada 1. janvāra līdz 2010. gada 31. decembrim. No šiem pacientiem atlasīti tie 74, kuriem AoCo korekcija veikta vecumā līdz 1 gadam, atsevišķi nodalot jaundzimušos līdz 28 dienu vecumam un zīdaiņus no 29. dienas līdz 12 mēnešu vecumam (1.1. attēls). No mirušo pacientu reǵistrācijas datiem atlasīti jaundzimušie un zīdaiṇi $(n=8)$, kuriem konstatēta AoCo laika posmā no 2000. gada 1. janvāra līdz 2010. gada 31. decembrim un kuri miruši kardiovaskulāras mazspējas (KVM) rezultātā bez operatīvas ārstēšanas vai kombinētas intrakardiālas patologijas un AoCo korekcijas laikā: 1) pacients ar dubultieplūšanu kreisajā ventrikulā (DILV), mağistrālo asinsvadu transpozīciju (MAT), ventrikulu starpsienas defektu (VSD), AoCo, 2) pacients ar trikuspidālā vārstuḷa (TV) atrēziju, MAT, AoCo miruši 1. un 2. dzīves dienā, 3) bērns ar izteiktu Ao loka hipoplāziju, AoCo, smagu KVM miris bez sirdskaites korekcijas 7 dienu vecumā, 4) pacients ar AoCo un atrioventrikulāru 
septālu defektu (AVSD), vēlīna diagnoze, miris bez operācijas KVM rezultātā, 5) pacients ar kritisku aortas stenozi (AoS) un AoCo, kas miris smagas KVM rezultātā 3. dzīves dienā, 6) pacients, kas miris 1 mēneša vecumā vienlaicīgas MAT, VSD, hipoplastiska Ao loka korekcijas operācijas beigās (smaga, ilgstoša hipoksēmija, ļoti vēlīna diagnoze), 7) pacients ar MAT, VSD, AoCo, kas miris KVM rezultātā bez operācijas, 8) pacients ar kreisās sirds hipoplāzijas robežstāvokli, kas miris pēc aortas loka korekcijas sakarā ar smagu kreisās sirds mazspēju. Turpmāk šo pacientu dati nav detalizēti apskatīti. Pacienti ar kreisās sirds hipoplāzijas sindromu nav iekḷauti pētījumā. Iegūtie dati analizēti saistībā ar dzimstības rādītājiem Latvijā no 2000. līdz 2010. gadam, izmantojot LR Centrālās statistikas pārvaldes datus.

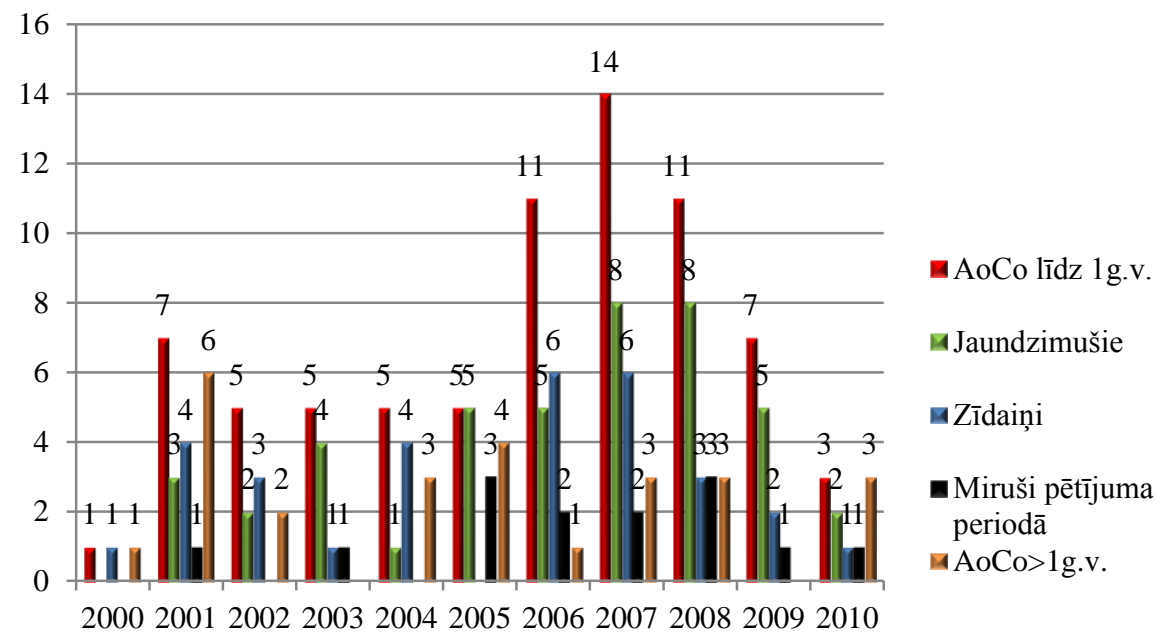

\section{1. att. Bērnu sadalījums pa vecuma grupām ar Latvijā koriǵētu aortas koarktāciju no 2000. līdz 2010. gadam $(n=100)$}

Lai analizētu AoCo kā no arteriāla vada atkarīgas sirdskaites atpazīstamību jaundzimušajiem un novēlotas diagnozes ietekmi uz pacienta klīnisko stāvokli un rezultātiem, atsevišķi analizēti klīniskie dati pacientiem, 
kuriem AoCo korekcija veikta līdz 2 mēnešu vecumam no 2005. gada 1. janvāra līdz 2010. gada 31. decembrim. Minētais laika posms izvēlēts sakarā ar Prostoglandīna E1 (PgE1) izmantojuma pieaugumu kopš 2005. gada. Retrospektīvi un prospektīvi analizēti klīniskie un laboratorie dati no pacientu slimības vēsturēm, ehokardiogrāfiskās atrades. Salīdzināti to pacientu dati, kurus nosūtījusi dzemdību iestāde (agrīna diagnoze), ar tiem gadījumiem, kad pacients stacionēts jau pēc izrakstīšanās no dzemdību iestādes (vēlīna diagnoze).

Lai izvērtētu AoCo ķirurğiskas ārstēšanas rezultātus jaundzimušajiem un zīdaiņiem, retrospektīvi (2000.-2007. gads) un prospektīvi (2008.2010. gads) analizēti visu to pacientu slimības vēsturu, ambulatoro kartinuu un ehokardiogrāfijas dati, kuriem veikta AoCo ķirurǵiska korekcija vecumā līdz 1 gadam no 2000. līdz 2010. gadam $(n=74)$. Pacienti sadalīi 3 grupās atkarībā no papildu intrakardiālas patologijas: I - pacienti ar vienkāršu AoCo ar ātriju starpsienas defektu (ASD) vai bez tā, II - pacienti ar AoCo un VSD, III pacienti ar kompleksu AoCo (kombinācijā ar dažādu intrakardiālu patologiiju).

No 74 pacientiem, kuriem pētījuma periodā zīdaiņa vecumā veikta AoCo korekcija, 14 pacienti miruši. No 60 dzīvajiem pacientiem bērna dalībai turpmākā pētījumā piekrituši 59 vecāki, 1 gadījumā vecāki atteikušies no dalības pētījumā, nav veikta šì pacienta izmeklēšana un datu analīze.

Pacienti pēc AoCo korekcijas novēroti dinamikā 70,7 $\pm 33,4$ mēnešus (minimums 20 mēnešus, maksimums 131 mēnesi). Pacientu atlase pētījumam, kā arī iznākumi saistībā ar lietoto ārstēšanu redzami 1.2. attēlā. Pacientu izmeklēšanai katra apmeklējuma laikā izmantota ehokardiogrāfija, analizēts pacienta augums, svars, ķermeņa laukums, arteriālais asinsspiediens (AS). Izmantoti Latvijas bērnu fiziskās attīstības normatīvi (Krūmiņa un Kokare, 2005). 
AoCo Prevalences analīze jaundzimušajiem Latvijā 2000. 2010. g.: bērni lídz 12 mēnešu vecumam ar AoCo diagnozi $\mathrm{n}=\mathbf{8 2}$

Tai skaitā 8 AoCo kombinācijā ar smagu intrakardiālu patologiju miruši bez VCC kirurǵiskas korekcijas/kombinētas VCC korekcijas laikā - turpmāk nav analizēti

Tālākā pētijumā iekḷautie pacienti

Ao Co korigiēta BKUS līdz 12 mēnešu vecumam 2000. g. - 2010. g.

$n=74$

2005.-2010. g. $\mathrm{n}=45$

AoCo korigêta līdz 2 mēnešu vecumam

(AoCo kā PDA atkarīgas VCC atpazistamības analīze)

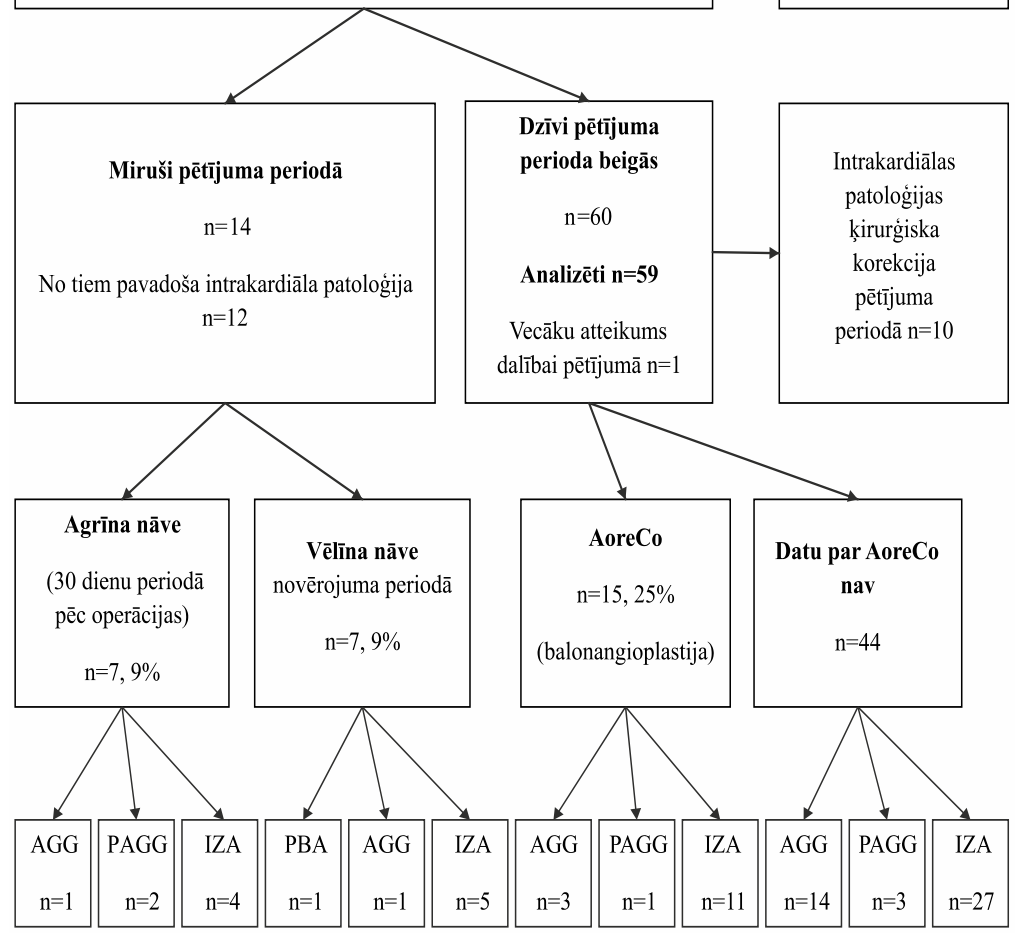

\section{2. att. Klīniskā pētījuma pacientu atlase un rezultāti saistībā ar lietoto ārstēšanas metodi}




\subsection{Pētījuma pacientu ehokardiogrāfiskā izmeklēšana}

Retrospektīvi analizēti visu $(n=74)$ pētījumā iekḷauto/operēto pacientu transtorakālās ehokardiogrāfijas ieraksti pirms operācijas un drīz pēc tās, analizēti aortas loka izmēri, hipoplāzijas pakāpe, plūsmas profils un gradients descendējošā aortā, kreisā ventrikula izmēri, funkcija, masa, asociēta intrakardiāla patolog̣ija. Sākot ar 2008. gadu, veikta atkārtota, prospektīva ehokardiogrāfiska izmeklēšana visiem dzivvajiem un dalībai pētījumā piekritušajiem pacientiem $(n=59)$.

Veikta standarta $M$ režīma, 2 dimensiju un krāsu doppler transtorakālā ehokardiogrāfija. Sirds anatomija un funkcija izvērtēta šādās pozīcijās: subkostāli, apikāli, parasternālā garā ass, parasternālā īsā ass, suprasternālā pozīcija. Aortas loka mērījumi veikti suprasternālajās garajās asīs, reizēm jaundzimušajiem lietojot modificētu augstu labo parasternālo projekciju šādos līmeņos: transversais loks (starp truncus brachiocephalicus un arteria carotis communis sinistra), isthmus daļa (šaurākais segments distāli no arteria subclavia sinistra atzarošanās vietas). Asinsvada diametri mērīti perpendikulāri gareniskajai asij maksimālas ekspansijas brīd̄i - sistolē. Iegūtie rezultāti attiecināti pret ķermeņa virsmas laukumu. Aortas loka obstrukcija izvērtēta secīgi, izmantojot nepārtraukta vilı̣na doplerogrāfiju (CWD) virzienā no proksimālā aortas loka līdz proksimālajai descendējošajai aortai. Rekoarktācija definēta kā spiediena gradients starp augšējām un apakšējām ekstremitātēm $\geq 20 \mathrm{~mm} \mathrm{Hg}$ vai maksimālais spiediena gradients descendējošā aortā CWD $(4 \times \mathrm{V}$ maksimālais $^{2}$ ) > $25 \mathrm{~mm} \mathrm{Hg}$.

Ehokardiogrāfijas protokols papildināts ar PWD doplerogrāfiskiem mērījumiem abdominālajā aortā diafragmas līmen̄̄ parasagitāli (abdominālā aorta garajā asī): maksimālais plūsmas ātrums sistolē (PWD S), minimālais plūsmas ātrums diastolē (PWD D), sistoliskās un diastoliskās plūsmas attiecība 
(PWD S/D). PWD S/D iegūts, attiecinot maksimālo plūsmas ātrumu sistolē pret minimālo plūsmas ātrumu diastolē (1.3. attēls).

Kreisā ventrikula izmēri mērīti $M$ režīmā papillāro muskuḷu līmen̄̄ parasternālajās garajās as̄is. Mērīts kreisā ventrikula izmērs diastoles beigās (LVEDD), kuru definēja QRS kompleksa sākums, kas mērīts kā attālums starp ventrikulu starpsienas endokarda virsmu un mugurējo sieniņu, kreisā ventrikula izmērs sistoles beigās (LVESD), ventrikulu starpsiena diastolē (IVSd), kreisā ventrikula mugurējā sieniņa diastolē (LVPWd). Saraušanās frakcija (FS) mērīta $M$ režīmā īsajās un garajās asīs (norma $28-38 \%$ ):

$$
\mathrm{FS}=(\text { LVEDD }- \text { LVEDS/LVEDD })
$$

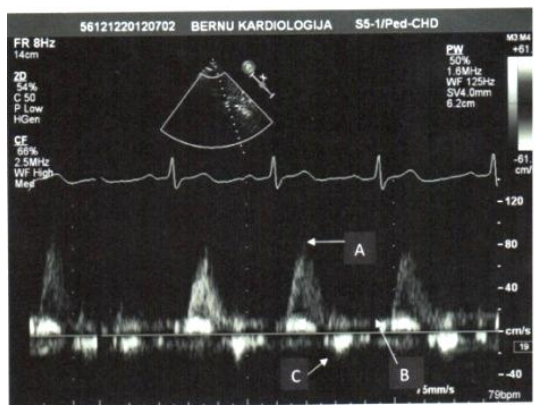

1.3. att. PWD plūsmas profils vēdera Ao pacientam bez Ao rekoarktācijas (A - maksimālais plūsmas ātrums sistolē, B - minimālais plūsmas ātrums diastolē, C - agrīna diastoliska atpakal̦plūsma)

Izsviedes frakcija (EF) mērīta 2 dimensiju režīmā:

$$
\mathrm{EF}=(\mathrm{EDV}-\mathrm{ESV} / \mathrm{EDV}) \times 100 \%
$$

Kreisā ventrikula masa kalkulēta, izmantojot mērījumus $M$ režīmā:

$$
\operatorname{LVM}=0,8\left(1,04\left([\mathrm{LVEDD}+\mathrm{LPWDd}+\mathrm{IVSd}]^{3}-[\mathrm{LVEDD}]^{3}\right)\right)+0,6 \mathrm{~g}(3)
$$


Kreisā ventrikula masas indekss (LVMi) aprēķināts, attiecinot LVM pret augumu 2,7. pakāpē (Foster et al., 2008). Mērījumu atbilstība pacienta antropometriskajiem rādītājiem (svaram, ķermeņa laukumam) izvērtēta, izmantojot normu tabulas un $z$ vērtības (Pettersen et al., 2008). Atrade pētījuma perioda beigās salīdzināta ar kontroles grupas pacientiem (28 bērni bez sirds patologiijas un blakus saslimšanām, $n=17$ zēni, $n=11$ meitenes), kas statistiski neatšķīrās no pētījuma grupas pēc dzimuma $(p=0,55)$ un vecuma $(p=0,69)$. Veicot retrospektīvu ehokardiogrāfijas ierakstu analīzi, tika izmantoti ieraksti, kas veikti ar Accuson Aspen un Hewlett Packard Sonos 4500 ehokardiogrāfijas aparatūru. Prospektīva ehokardiogrāfija veikta, izmantojot Philips iE33 un HD11XE ehokardiogrāfijas aparātus un divdimensiju (2D), pulsa vilı̣na (PWD), nepārtrauktā viļ̣na (CWD) doppler bērnu kardiologijas programmas ar sektora zondi 3-5-8-12 MHz. Jaundzimušajiem un maziem zīdainiem lietota sektora zonde ar 5-12 MHz.

\subsection{Aortas loka biomehāniskā pētījuma materiāls un metodes}

Saņemta BKUS Ētikas komisijas aţ̦auja darba veikšanai. Laika posmā no 2009. gada aprīḷa līdz 2011. gada decembrim autopsiju laikā iegūti 20 descendējošās aortas augšdaļas paraugi $40 \mathrm{~mm}$ garumā- materiāls no jaundzimušajiem un zīdaiṇiem bez aortas koarktācijas vecumā no 1 dienas līdz 5 mēnešiem (vidējais vecums 31,9 \pm 49,3 dienas, mediāna 6 dienas, 95\% TI 6,7-58 dienas), svars 2,0-6,7 kg (vidējais svars 3,9 $\pm 1,3 \mathrm{~kg}$ ). Pirms paņemšanas paraugs marķēts, saglabājot in situ aksiālu ekstensiju. Paraugi uzglabāti Kustadiola perfūzijas šķīdumā līdz 24 stundām $2-4{ }^{\circ} \mathrm{C}$ temperatūrā. Asinsvada sieniņas galveno biomehānisko īpašību noteikšanai izmantots slogošanas stends, ar kura palīdzību var noteikt iekšējo spiedienu, aksiālo spēku, garenvirziena un šķērsvirziena deformācijas, parauga diametra izmaiṇas 
reǵistrētas ar digitālo videokameru, kas pieslēgta datoram (1.4. attēls). Eksperimenta laikā artērijas segmenti slogoti ar spiedienu no 0 līdz $220 \mathrm{~mm}$ $\mathrm{Hg}$, parauga garumu $L$ saglabājot nemainīgu. Spiediens paaugstināts ar soli $20 \mathrm{~mm} \mathrm{Hg}$, noturot to konstantu 1 minūti katra soḷa ietvaros.

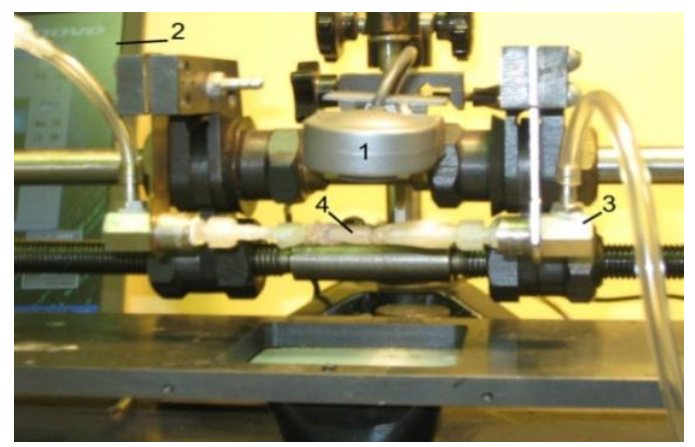

1.4. att. Slogošanas stends iekšējā spiediena, aksiālo spēku, garenvirziena un šksēersvirziena deformācijas noteikšanai: 1- videokamera, 2 - dators, 3 - spiediena devējs, 4 - paraugs (aorta)

Sākotnējais ārējais diametrs pie iekšējā $p=0 \mathrm{~mm} \mathrm{Hg}$ apzīmēts kā $D_{0}$. Diametrs mērīts katrā spiediena līmenī. Sieniņas biezums $h$ aprēķināts šādi:

$$
h=h_{\mathrm{O}} \times \lambda_{3}
$$

kur

$$
\begin{aligned}
& \lambda_{3}=\frac{1}{\lambda_{1} \times \lambda_{2}} \\
& \lambda_{2}=\left(D / D_{O}\right)
\end{aligned}
$$

Aploces spriegums:

$$
\sigma=\frac{p R}{h}
$$

kur

$p-$ iekšejais spiediens

$R$ - rādiuss

$$
\lambda_{1}=\left(\mathrm{L} / \mathrm{L}_{0}\right)=1,0
$$


Šajos vienādojumos $h_{0}$ ir parauga sākotnējais sieniṇas biezums un $\lambda_{1}, \lambda_{2}$, un $\lambda_{3}$ pagarinājuma kārtnība garenvirziena, aploces un radiālā virzienā. Tā kā artērijas garums tika saglabāts konstants $L_{0}, \lambda_{1}\left(=\mathrm{L} / L_{0}\right)$ vērtība bija 1. Sākotnējais sieniņas biezums $h_{0}$ tika mērīts ar ketetometru KM-6 ar $\pm 0,001 \mathrm{~mm}$ precizitāti. Artērija pirms testa sagatavota, cikliski slogojot, lai nodrošinātu stabilu stāvokli, kas sniegtu reproducējamu mehānisku atbildi. Šajā procesā asinsvads tika slogots ar spiedienu 0-200 mm Hg 20 piegājienos (soḷos) piecas reizes, noturot konstantu spiedienu 1 minūti katra soḷa ietvaros. Sākotnējās līknēs vērojama būtiska histerēze, taču trešā un ceturtā cikla laikā iegūtas līknes ar minimālu histerēzi. Elastības modulis $E$ kalkulēts kā modulis starp diviem spriegumiem (iekšèjā spiediena vērtībām) (1.5. attēls).

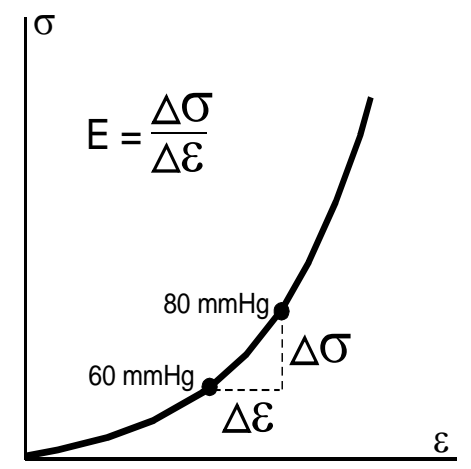

\section{5. att. Shematisks attēls elastības moduḷa izskaiț̣ošanai}

Analizēti 20 paraugi: 10 natīvas aortas paraugi, 3 paraugi ar izveidotu anastomozi gals-galā (AGG), 4 paraugi ar pagarinātu anastomozi gals-galā (PAGG) un 3 paraugi ar izveidotu kreisās zematslēgas artērija ielāpu (IZA). Anastomozes izveidoja ķirurgs, kurš ikdienā klīnikā veic AoCo korekcijas operācijas, izmantojot šuvju tehniku, kas ir identiska aortas loka plastikai in vivo (Prolēna 6,0-7,0 nepārtraukta šuve mugurējā sieniņā un vairākas pārtrauktas šuves descendējošās aortas priekšējā sieniņā). 


\subsection{Datu statistiskā apstrāde}

Datu apkopošanai un uzglabāšanai izmantota programma Microsoft Office Excel 2003, datu statistiskā apstrāde veikta ar programmu SPSS 16.0 (SPSS Inc., Čikāga, ASV).

Klīnisko un antropometrisko datu raksturošanai lietotas vispārpieņemtās aprakstošās statistikas metodes. Aprēķināti centrālās tendences rādītāji (vidējais aritmētiskais, mediāna, moda) un izkliedes rādītāji (dispersija, standartnovirze), kā arī kategorisku vērtīibu grupu procenti.

Darbā ar neatkarīgu izlašu $t$-testu pārbaudītas statistiskās hipotēzes par grupu vidējo vērtību un izkliežu vienādību. Vairāku pacientu grupu salīdzināšanai izmantota viena faktora dispersiju analīze (ANOVA). Datu atbilstīiba normālajam varbūtību sadalījumam pārbaudīta ar KolmogorovaSmirnova testu. Divu vai vairāku mainīgo lielumu savstarpējai salīdzināšanai izmantotas korelācijas un regresijas analīzes metodes. Korelācijas koeficients kā sakarības ciešuma kvantitatīvs rādītājs starp diviem vai vairākiem mainīgajiem lielumiem aprēķināts gan mērītiem lielumiem (Pīrsona korelācijas koeficients), gan rangu skalas lielumiem (Spīrmena korelācijas koeficients). Pētījumā sakarības ciešums starp mainīgajiem, balstoties uz korelācijas koeficienta $r$ lielumu, vērtēts kā vājšs, ja $r=0-0,4$, kā vidēji ciešs, ja $r=0,4-0,7$, kā ciešs, ja $r=0,7-1,0$.

Pacientu grupu salīdzināšanai lietots Fišera eksaktais tests vai Pīrsona $\chi^{2}$ tests. Proporciju izvērtēšanai aprēķināts arī 95\% ticamības intervāls (TI). Lai novērtētu dzīvildzes funkciju, kā arī reintervences nepieciešamību sakarā ar rekoarktāciju, lietots Kaplana-Meijera modelis. Datu statistiskās analīzes rezultātā novērtēti pētāmo pazīmju parametri grupās, pārbaudīta pazīmju savstarpējā saistība, izvērtējot statistiskās hipotēzes būtiskuma līmeni $p$. Par statistiski ticamu pieņemta $p$ vērtība, kas $<0,05$. 


\section{REZULTĀTI}

\subsection{Aortas koarktācijas prevalence jaundzimušajiem Latvijā 2000.-2010. gadā}

Laikā no 2000. līdz 2010. gadam aortas koarktācijas prevalence bija 3,4 $\pm 1,3$ no 10000 dzīvi dzimušajiem. Laika posmā no 2000. līdz 2004. gadam AoCo prevalence bija 2,6 $\pm 0,9$, bet no 2005. līdz 2010. gadam $-4,2 \pm 1,2$ no 10000 dzīvi dzimušajiem $(p=0,094)$.

\subsection{Aortas koarktācijas kā no arteriāla vada atkarīgas sirdskaites atpazistamība Latvijā 2005.-2010. gadā}

BKUS laika posmā no 2005. gada 1. janvāra līdz 2010. gada 31. decembrim sakarā ar AoCo ārstēti 45 bērni vecuma grupā līdz 2 mēnešiem. No tiem 14 (31\%) bija jaundzimušie un 31 (69\%) zīdainis līdz 2 mēnešu vecumam. Iegūtie dati liecina, ka 64\% $(n=29)$ pacientu nosūtījusi dzemdību iestāde (agrīna diagnoze), bet 36\% $(n=16)$ bērnu tika nosūtīti no reǵionāla stacionāra jau pēc izrakstīšanās no dzemdību iestādes, vai tos nosūtīja ǵimenes ārsts (vēlīna diagnoze). Nosūtīšanas diagnoze bija AoCo vai aizdomas par VCC ar kardiovaskulāru mazspēju 73\% $(n=33)$ gadījumu, taču aizdomas par citām saslimšanām bija 27\% ( $n=12)$ gadījumu (2.1. attēls). Aizdomas par VCC kā nosūtǐšanas diagnoze konstatēta 93\% gadījumu, kad bērnu nosūta dzemdību iestāde, tomēr tikai 38\% gadījumu, kad bērns stacionēts jau pēc izrakstīšanās no dzemdību iestādes (Fišera eksaktais tests, $p=0,0001$, Spīrmena $r=0,602$, $p=0,0001)$. Izolēta AoCo tika diagnosticēta vēlīni daudz biežāk (52\%) nekā AoCo kombinācijā ar pavadošu intrakardiālu patologiju (18\%) (Fišera eksaktais 
tests, $p=0,029)$. Lielākā dạ̧a bērnu ar AoCo kombinācijā ar VSD (77\%, $n=10)$ vai kompleksu AoCo $(89 \%, n=8)$ tika nosūtīti ārstēšanai no dzemdību iestādes. Izolēta AoCo novērota 75\% $(n=12)$ bērnu, kuri nosūtīti pēc izrakstīšanās no dzemdību iestādes $\left(\chi^{2}=6,0\right.$, df2, $\left.p=0,05\right)$.

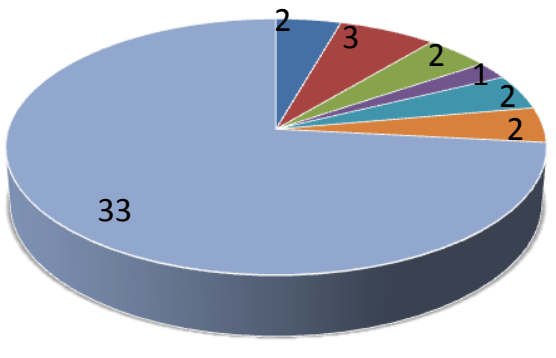

\author{
- Ieilgusi dzelte \\ - Obstruktīvs bronhīts, \\ pneimonija \\ - Iedzimta genētiska patologija \\ - Aspirācija? \\ - Gremošanas, barošanās \\ traucējumi \\ - Sepse? \\ " VCC vai AoCo?
}

\title{
2.1. att. Nosūtī̌sanas diagnozes jaundzimušajiem un zīdaiņiem līdz 2 mēnešu vecumam ar aortas koarktāciju 2005.-2010. gadā $(n=45)$
}

Pacienta vecums diagnozes noteikšanas brīdī bija 16,2 \pm 19,8 dienas (minimums 1, maksimums 60, vidēji 5), pacientu vecums operācijas brīdī bija 23,5 $\pm 19,8$ dienas (minimums 2, maksimums 61, vidēji 13), svars 3,5 $\pm 0,8 \mathrm{~kg}$ (minimums 2, maksimums 5). Antenatāli aug̣̦a EHOKG aizdomas par AoCo izteiktas $27 \%(n=12)$ gadījumu. Pētījuma grupā bija 51\% $(n=23)$ pacientu ar izolētu AoCo, 29\% ( $n=13)$ pacientu bija AoCo kombinācijā ar VSD, 20\% $(n=9)$ pacientu bija kompleksa koarktācija (AoCo kombinācijā ar tādām intrakardiālām patologiijām kā mitrāla stenoze (MS), aortas stenoze (AoS), dubultatiešana no labā ventrikula (DORV) ar VSD). Konstatēta mērena korelācija starp pavadošu intrakardiālu patologiju un antenatālu diagnozi (Spīrmena $r=0,407, p=0,006, n=45$ ). PgEl bija lietots $100 \%$ gadījumu, kad 
aizdomas par sirdskaiti izteiktas antenatāli, un 48\% postnatāli konstatēto gadījumu.

Agrīnas un vēlīnas diagnozes ietekme izolētu AoCo grupā parādīta 2.1. tabulā. Bērniem ar izolētu AoCo agrīnas diagnozes gadījumā pirmsoperācijas periodā nebija nepieciešama inotropa stimulācija, mākslīga plaušu ventilācija un tika novēroti normāli skābju-sārmu līdzsvara rādītāji asin̄̄s. Acidoze kapilārajās asin̄̄s $(P h 7,18 \pm 0,04)$ novērota 33\% bērnu, kuri tika hospitalizēti no mājām. Novērots pa vienam agrīnas postoperatīvas nāves gadījumam gan agrīnas, gan vēlīnas diagnozes gadījumā izolētu AoCo grupās. Agrīnas diagnozes gadījumā nāves cēlonis bija sepse, bet vēlīnas diagnozes gadījumā - pneimonija un pulmonāla hipertensija.

No 9 pacientiem ar kompleksu AoCo tikai vienā gadījumā pacients stacionēts jau pēc izrakstī̌anas no dzemdību iestādes (AoCo kombinācijā ar supravalvulāru AoS). Lielāko dalı pacientu $(n=8)$ nosūtīja dzemdību iestāde, un tie saņēma $\mathrm{PgE}_{l}$. Šiem bērniem nebija nepieciešama inotropa stimulācija un mākslīga plaušu ventilācija pirmsoperācijas periodā.

No 13 pacientiem ar AoCo kombinācijā ar VSD bija tikai 3 vēlīnas diagnozes gadījumi, starp kuriem nebija agrīnas nāves gadījumu. No 10 pacientiem ar AoCo kombinācijā ar VSD ar agrīnu diagnozi 5 gadījumos bija nepieciešams inotrops atbalsts un 4 gadījumos mākslīga plaušu ventilācija pirmsoperācijas periodā. No šiem pacientiem 3 ar agrīnu diagnozi gāja bojā agrīni postoperatīvi smagas kardiovaskulāras mazspējas rezultātā.

Cox regresijas analīze parādīja, ka nav sakarības starp agrīnu mirstību (30 dienu laikā pēc operācijas) un diagnozes laiku visās grupās. Vēlīna diagnoze ietekmēja pacienta stāvokli preoperatīvi bērniem ar izolētu AoCo, kā arī nepieciešamību pēc ilgstošākas intensīvas terapijas pirmsoperācijas periodā $(p=0,046)$. 
2.1. tabula

Izolētas aortas koarktācijas pacientu salīdzinājums līdz 2 mēnešu vecumam ar agrīnu un vēlīnu diagnozi 2005.-2010. gadā

\begin{tabular}{|c|c|c|c|}
\hline Faktors & $\begin{array}{c}\text { Agrīna } \\
\text { diagnoze } \\
(n=11)\end{array}$ & $\begin{array}{c}\text { Vèlīna } \\
\text { diagnoze } \\
(n=12)\end{array}$ & $P$ vērtība \\
\hline Acidoze kapilārās asinīs & 0 & $4(33 \%)$ & $0,014^{1}$ \\
\hline $\begin{array}{l}\text { Inotropa stimulācija pirmsoperācijas } \\
\text { periodā }\end{array}$ & 0 & $3(25 \%)$ & $0,038^{1}$ \\
\hline $\begin{array}{l}\text { Mākslīga plaušu ventilācija } \\
\text { pirmsoperācijas periodā }\end{array}$ & 0 & $3(25 \%)$ & $0,038^{1}$ \\
\hline $\begin{array}{l}\text { Laiks no uzņemšanas līdz operācijai } \\
\text { (dienas) }\end{array}$ & $4,6 \pm 2,2$ & $7,3 \pm 3,5$ & $0,046^{2}$ \\
\hline Vecums diagnozes brīdī (dienas) & $8,7 \pm 16,9$ & $32,1 \pm 15,6$ & $0,003^{2}$ \\
\hline Svars operācijas brīdī (kg) & $3,3 \pm 0,6$ & $4,1 \pm 0,6$ & $0,004^{2}$ \\
\hline Agrīna mirstība & 1 & 1 & NS* \\
\hline
\end{tabular}

\subsection{Koarktācijas ķirurğiskās ārstēšanas rezultāti jaundzimušajiem un zīdaiņiem Latvijā 2000.-2010. gadā}

Laika posmā no 2000. gada 1. janvāra līdz 2010. gada 31. decembrim BKUS AoCo k̦irurǵiska korekcija veikta 74 bērniem līdz 12 mēnešu vecumam: 44 zēniem (59\%) un 30 meitenēm (41\%) (2.2. attēls). Vidējais pacientu vecums primāras AoCo ķirurǵiskas korekcijas brīdī bija $47 \pm 58$ dienas (min. - 2, maksim. - 243, mediāna - 24 dienas), no 2000. gada līdz 2004. gadam $68,7 \pm 67,3$ dienas (mediāna - 51 diena), bet no 2005. gada līdz 2010. gadam $37,7 \pm 51,6$ dienas (mediāna -20 dienas) $(p=0,033)$. Pacienta vidējais svars AoCo korekcijas brīd̄̄ bija 4,2 $\pm 1,6 \mathrm{~kg}$. Indikācijas AoCo ķirurğiskai korekcijai visiem bērniem bija konservatīvi neārstējama kardiovaskulāra mazspēja. 


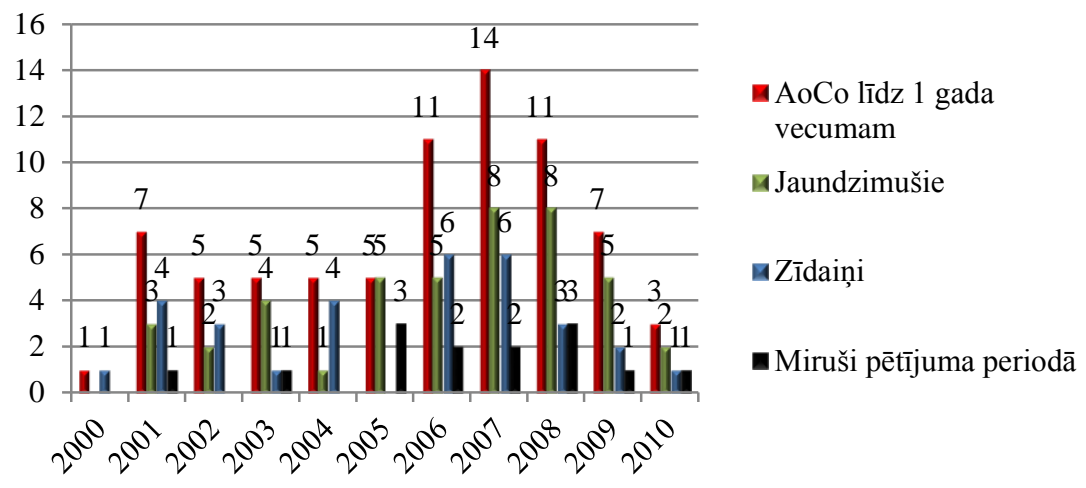

2.2. att. Aortas koarktācijas ķirurğiskas ārstēšanas rezultāti jaundzimušajiem un zīdaiṇiem BKUS Bērnu kardiolog̣ijas un kardioḳirurğijas klīnikā 2000.-2010. gadā

Antenatāla diagnoze noteikta $19 \%$ gadījumu (4\% laika posmā no 2000. līdz 2004. gadam un $25 \%$ laika posmā no 2005. līdz 2010. gadam, $\chi^{2}=4,62, \quad$ df1, $\left.p=0,032\right)$. Nepieciešamība pēc inotropas stimulācijas pirmsoperācijas periodā bija $20 \%$ gadījumu, un $18 \%$ gadījumu tika lietota mākslīgā plaušu ventilācija (MPV) preoperatīvi. Intensīvas terapijas nepieciešamība pirms operācijas būtiski statistiski neatšķīrās laika posmos no 2000. līdz 2004. gadam un no 2005. līdz 2010. gadam. Inotropa stimulācija preoperatīvi no 2000. līdz 2004. gadam lietota 6 no 23 pacientiem, bet no 2005 . līdz 2010. gadam 9 no 51 pacienta $\left(\chi^{2}=0,69\right.$, df1, $p=0,403$, Fišera eksaktais tests $p=0,533)$. MPV preoperatīvi no 2000. līdz 2004. gadam lietota 6 no 23 pacientiem, bet no 2005. līidz 2010. gadam 7 no 51 pacienta $\left(\chi^{2}=1,673\right.$, df1, $p=0,196$, Fišera eksaktais tests $p=0,206$ ).

Pēc sirdskaites anatomijas saistībā ar intrakardiālu patologiju pacientu sadalījums pa grupām: I grupa (vienkārša AoCo ar vai bez ASD) 57\%, II grupa (pacienti ar AoCo un VSD) 23\%, III grupa (kompleksa koarktācija) 20\% (2.2. tabula).

Infantila jukstaduktāla AoCo ar isthmus daḷas hipoplāziju novērota 83\% ( $n=62)$ gadījumu, postduktāla AoCo $-4 \%(n=3)$ un jukstaduktāla 
membrāna - 12\% $(n=9)$ gadījumu. Aortas loka hipoplāzija (transversā aortas loka šķērsizmērs zem $-2 z$ vērtībām attiecībā pret pacienta ķermeņa laukumu) bija 16 pacientiem.

Pētījuma grupā lietotās AoCo kirurğiskas korekcijas metodes bija vienkārša anastomoze gals-galā 26\% $(n=19)$ (AGG), aortoplastija ar kreisās zematslēgas artērijas lēveru 65\% $(n=48)$ (IZA), pagarināta anastomoze galsgalā $8 \%$ gadījumu $(n=6)$ (PAGG), vienam pacientam veikta primāra AoCo balonangioplastija (PBA).

Agrīna postoperatīva mirstība 30 dienu laikā pēc operācijas novērota 7 gadījumos (9\%) (nāves cēloṇi: 1 gadījumā sepse, 4 gadījumos smaga kardiovaskulāra mazspēja, 1 gadījumā akūta nieru mazspēja, 1 gadījumā pneimonija un pulmonāla hipertensija).

Turpmāk pētījuma periodā novēroti 7 vēlīnas nāves gadījumi. Nāves cēloṇi bija 2 endokarda fibroelastozes gadījumi, 2 nāves ārpus BKUS (autopsija BKUS nav veikta), 1 gadījumā abpusēja pneimonija, 1 gadījumā smaga kardiovaskulāra mazspēja, dekompensēta metabola acidoze, aizdomas par sepsi (pacientam nav veikta autopsija), 1 pacients miris 3,5 mēnešu vecumā smagas kombinētas intrakardiālas patoloǵijas korekcijas laikā.

Pētīto pacientu grupā netika novērots neviens apakšējās paraplēgijas gadījums, taču vienam pacientam pēcoperācijas periodā attīstījusies kreisās puses hemiparēze. Pacientu dz̄ivildzes funkciju pētījuma periodā raksturo Kaplana-Meijera līkne (2.3. attēls), dzīvildze pētījuma periodā saistīta ar intrakardiālu patologiiju (2.4. attēls). 
Aortas koarktācijas pacientu sadalījums saistībā ar intrakardiālu patoloğiju līdz 12 mēnešu vecumam 2000. -2010. gadā $(n=74)$

\begin{tabular}{|c|c|c|}
\hline $\begin{array}{c}\text { Pacientu } \\
\text { grupa }\end{array}$ & Intrakardiāla patologiija & $\begin{array}{c}\text { Pacientu } \\
\text { skaits }\end{array}$ \\
\hline I grupa & Nav (izolēta AoCO) \pm ASD & $42(57 \%)$ \\
\hline II grupa & $\mathrm{AoCo}+\mathrm{VSD}$ & $17(23 \%)$ \\
\hline \multirow{10}{*}{ III grupa } & Kompleksa AoCo: & $15(20 \%)$ \\
\hline & - DORV + VSD & 1 \\
\hline & - subvalvulāra AoS + VSD & 1 \\
\hline & - subvalvulāra AoS & 4 \\
\hline & - valvulāra AoS & 4 \\
\hline & - supravalvulāra AoS & 1 \\
\hline & - mitrālā vārstul̦a nepietiekamība (vārstuḷa patolog̣ija) & 1 \\
\hline & - mitrāla stenoze + VSD & 1 \\
\hline & - atrioventrikulārs septāls defekts & 1 \\
\hline & - plaušu artērijas stenoze + ASD & 1 \\
\hline
\end{tabular}

Pētījuma perioda beigās dzīvi bija $81,1 \%$ pacientu $(95 \%$ TI kumulatīva dzīvildze 99,3-123,5 mēneši) (2.3. attēls). Atsevišķi analizējot pa pacientu grupām saistībā ar pavadošu intrakardiālu patoloǵiju: kumulatīva dzīvildze pacientiem ar izolētu AoCo konstatēta 95\% gadījumu (95\% TI 121,8139,3 mēneši), AoCo kombinācijā ar VSD - 59\% (95\% TI 35,0-79,9 mēneši), ar kompleksu AoCo - 67\% gadījumu (95\% TI 52,7-108,9 mēneši) $(p=0,001)$ (2.4. attēls).

Kumulatīva dzīvildze dažādu operācijas metožu lietojuma gadījumā statistiski ticami neatšķīāā: AGG 89,5\% (95\% TI 104,1-141,4 mēneši), IZA 81\% (95\% TI 84,7-111,6 mēneši), PAGG 67\% (95\% TI 38,1-135,7 mēneši) $(p=0,371)$. 
Letālo gadījumu grupā pētījuma periodā biežāk diagnoze bija noteikta jau antenatālā periodā, kas saistīts ar asociētu intrakardiālu patologiju $\left(\chi^{2}=6,45\right.$, df1, $\left.p=0,01\right)$, pirmsoperācijas periodā biežāk lietota inotropa stimulācija $\left(\chi^{2}=5,45\right.$, df1, $\left.p=0,02\right)$, biežāk bijusi nepieciešama mākslīga plaušu ventilācija $\left(\chi^{2}=7,63\right.$, df1, $\left.p=0,006\right)$, biežāk pacientam bija hipoplastisks aortas loks (Fišera eksaktais tests, $p=0,0001$ ).

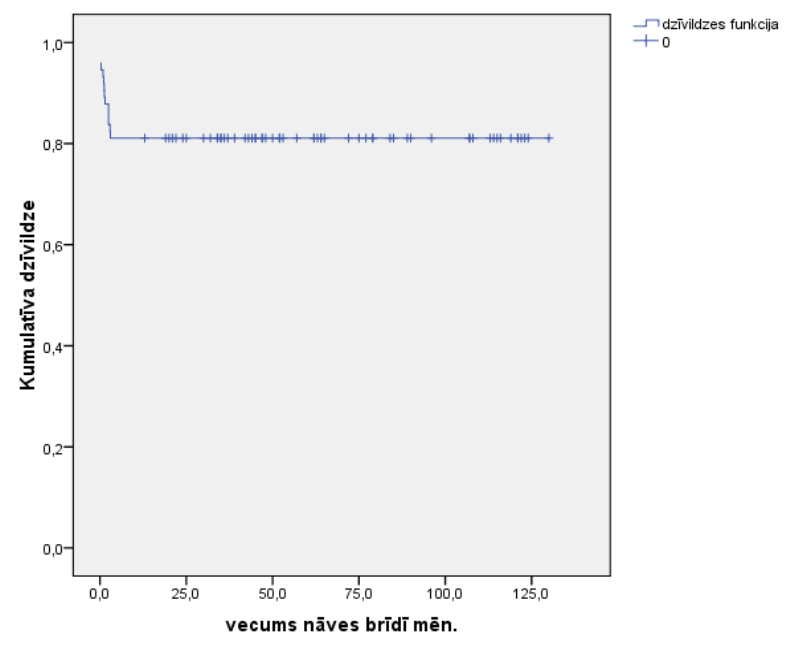

\section{3. att. Kumulatīva dzīvildze jaundzimušajiem un zīdaiņiem ar} aortas koarktāciju pētījuma grupā $(n=74)$

Pastāv mērena korelācija starp bojāeju pētījuma periodā un asociētu intrakardiālu patolog̣iju (Spīrmena korelācijas koeficients $r=0,402, n=74$, $p=0,0001)$. 


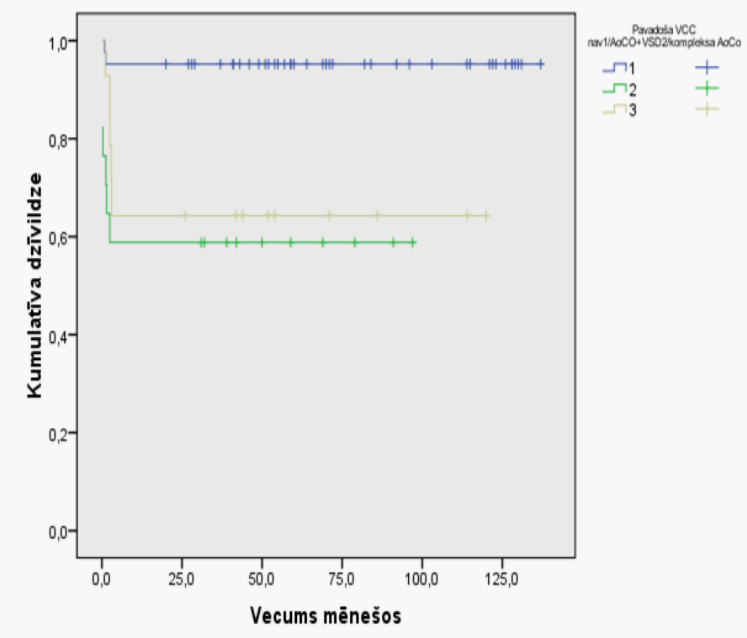

2.4. att. Dz̄̄vildze jaundzimušajiem un zīdaiņiem ar aortas koarktāciju saistībāā ar intrakardiālu patologiju $(n=74)$ : 1 - izolēta AoCo, 2 - AoCo + VSD, 3 - kompleksa AoCo

Novērošanas periodā Ao rekoarktācija (spiediena gradients descendējošā aortā > 25 mm Hg miera stāvoklī kombinācijā ar descendējošās aortas lūmena sašaurinājumu $\geq 50 \%$ un hipertensiju augšejās ekstremitātēs) attīstījās 15 pacientiem (25\%, izslēdzot letālos gadījumus) vecumā no 2 mēnešiem līdz 8 gadiem, 73\% gadījumu AoCo ķirurǵiskā ārstēšana veikta jaundzimušo vecumā. Pirmajā gadā pēc primāras sirdskaites korekcijas rekoarktācija attīstījusies $60 \%$ gadījumu. Netika konstatēta statistiski ticama atšķirība starp rekoarktācijas attīstību dažādu AoCo ķirurğiskas korekcijas metožu gadījumā: 18\% AGG grupā, 29\% IZA grupā, 25\% PAGG grupā $p=0,67)$ (2.5. attēls).

Visiem pacientiem veikta rekoarktācijas zonas balonangioplastija 35,7 $\pm 33,7$ mēnešu vecumā (vecums 2 mēneši -8 gadi). Pacienti novēroti dinamikā 70,7 $\pm 33,4$ mēnešus (minimāli 18, maksimāli 131 mēnesi), vecums 
pētījuma perioda beigās 1 gads 6 mēneši līdz 11 gadi 3 mēneši $(73,2 \pm 34,4$ mēneši, 95\% TI 64,2-82,1 mēneši).

Antihipertensīvu terapiju pētījuma perioda beigās saņēma 4 no 59 pacientiem (7\%) bez konstatēta nozīmīga reziduāla gradienta, 5 pacientiem arteriālais asinsspiediens atbilda 90. procentilei, taču 1 pacientam 95. procentilei (prehipertensija/hipertensija 10\%), pārējiem pacientiem arteriālā spiediena mērījumu rezultāti bija robežās līdz 75. procentilei. Nevienam pacientam nenovēroja aortas aneirismas veidošanos.

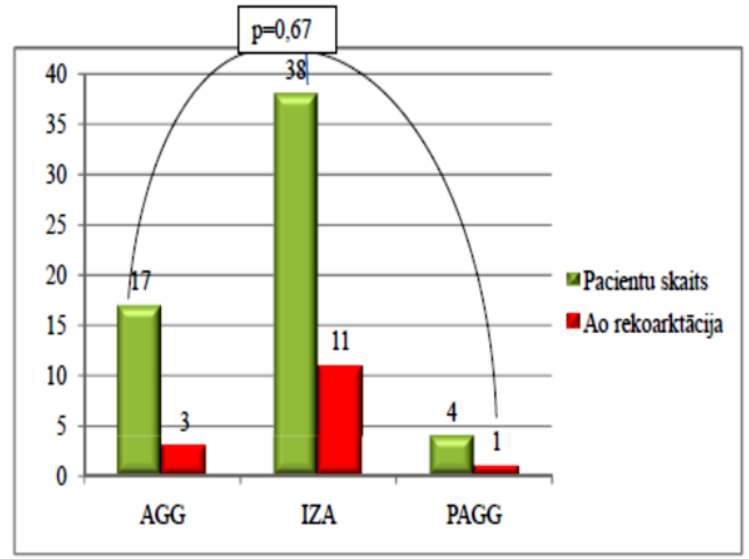

\section{5. att. Aortas rekoarktācija pēc dažādu ķirurğiskas ārstēšanas metožu lietošanas}

Abu roku augšdelmi un apakšdelmi mērīti pacientiem, kuriem AoCo korekcijai bija izmantots ielāps ar kreiso zematslēgas artērijas lēveru ( $n=34,89 \%$ ), pacienta vecums mērījuma brīdī bija $4,7 \pm 2$ gadi. Šiem pacientiem labās rokas augšdelms bija 21,32 $\pm 3,6 \mathrm{~cm}$ garš, bet kreisās rokas augšdelms $-21,22 \pm 3,7 \mathrm{~cm}(p=0,92)$, labās rokas apakšdelms 16,08 $\pm 2,6 \mathrm{~cm}$, bet kreisās rokas apakšdelms $-15,97 \pm 2,6 \mathrm{~cm}(p=0,86)$. Četriem pacientiem 
novērota 1̄sāka kreisā augšējā ekstremitāte salīdzinājumā ar labo, kreisās puses augšdelms bija īsāks par 0,5-1,0 cm, taču apakšdelms īsāks par $0,5-0,7 \mathrm{~cm}$, vēl vienam pacientam novērota neizteikta roku plaukstu asimetrija (kreisā nedaudz mazāka par labo). Kopumā roku garuma atšksirības novērotas 14,7\% pacientu IZA grupā, taču nevienā gadījumā ne pacienta vecāki, ne arī paši pacienti neatzīmēja funkcionālus traucējumus.

\subsection{Ehokardiogrāfisks novērtējums pacientiem ar agrīnā vecumā koriğētu koarktāciju Latvijā 2000.-2010. gadā}

Ehokardiogrāfisks novērojums vidēji ilgā termiņā tika veikts 35 zēniem (59\%) un 24 meitenēm (41\%). No šiem pacientiem 46\% $(n=27)$ bija operēti kā jaundzimušie, bet 54\% $(n=32)$ kā zīdaiņi. Primārā AoCo ķirurğiskās ārstēšanas metode bija AGG 29\% $(n=17)$, PAGG 7\% $(n=4)$ un IZA 64\% gadījumu $(n=38)$. Pacientu raksturojums AoCo ķirurǵiskas korekcijas brīdī sniegts 2.3. tabulā.

Pirms AoCo ķirurǵiskas korekcijas spiediena gradients CWD doplerogrāfiski (CWD Pg maks.) descendējošā Ao bija $62 \pm 23$ mm Hg, LVDd $20,9 \pm 5,6 \mathrm{~mm}, \quad$ IVSd $6,2 \pm 1,7 \mathrm{~mm}, \quad$ LVPWd $4,8 \pm 1,2 \mathrm{~mm}$. Pavadoša intrakardiāla patologija bija 21 no 59 pacientiem (36\%) (2.4. tabula). Tikai 7 pacientiem (12\%) novērots divviru Ao vārstulis.

Kreisā ventrikula masa (LVM) pirms ķirurğiskas korekcijas bija 22,9 $\pm 13,8$ g (mērīta pacientiem bez AoS, MS, PS, $n=49$ ). Transversā Ao loka izmērs bija 7,1 $\pm 1,4 \mathrm{~mm}$ (95\% TI 6,7-7,5 mm). Hipoplastisks transversais Ao loks konstatēts 8 gadījumos $(13 \%)(z$ vērtība $\leq-2)$ (2.6. attēls). Aortas koarktācijas zonas diametrs bija 2,5 $\pm 0,7 \mathrm{~mm}$. 
2.3. tabula

Pacientu raksturojums AoCo primāras ķirurğiskas ārstēšanas dienā $(n=59)$

\begin{tabular}{|c|c|c|c|c|}
\hline \multirow{2}{*}{ Parametrs } & Vidējā vērtība & $\begin{array}{c}\text { Standart- } \\
\text { novirze }\end{array}$ & \multicolumn{2}{|c|}{ 95\% TI } \\
\cline { 4 - 5 } & & & Minimāli & Maksimāli \\
\hline $\begin{array}{c}\text { Vecums operācijas } \\
\text { brīdī (dienas) }\end{array}$ & 55,37 & $\pm 61,34$ & 2 & 243 \\
\hline Svars (kg) & 4,41 & $\pm 1,74$ & 1,7 & 9,6 \\
\hline Augums (cm) & 55,75 & $\pm 6,40$ & 45 & 76 \\
\hline $\begin{array}{c}\text { Ķermeña laukums } \\
\left(\mathrm{m}^{2}\right)\end{array}$ & 0,26 & $\pm 0,07$ & 0,15 & 0,46 \\
\hline
\end{tabular}

Pacientiem ar AoCo un VSD konstatēts šaurāks Ao transversais loks salīdzinājumā ar pacientiem, kuriem bija izolēta AoCo $(6,2 \pm 1,5 \mathrm{~mm}$ pretstatā 7,4 $\pm 1,3 \mathrm{~mm}, p=0,015)$. Pacientiem, kuriem primārai koarktācijas ķirurǵiskai ārstēšanai lietota AGG, Ao transversais loks bija 7,9 $\pm 1,5 \mathrm{~mm}$, salīdzinoši šaurāks IZA gadījumā - 6,8 $\pm 1,3$ mm ( $p=0,007$, salīdzinot AGG ar IZA), un 6,5 $\pm 1,3$ mm PAGG gadījumā $(p=0,66$, salīdzinot IZA ar PAGG). Pirms AoCo ķirurğiskas korekcijas 17\% $(n=10)$ pacientu novērota pazemināta kreisā ventrikula sistoliskā funkcija (EF < 55\%). Pēc AoCo primāras ķirurǵiskas ārstēšanas maksimālais CWD Pg descendējošā Ao bija 18,63 99 mm Hg, visiem pacientiem bija palpējams femorālais pulss, netika novērota nozīmīga reziduāla koarktācija. Tikai vienam pacientam novērota pazemināta kreisā ventrikula sistoliskā funkcija. 
Pavadoša intrakardiāla patolog̣ija ehokardiogrāfiski ilgstoši novērotiem pacientiem $(n=59)$

\begin{tabular}{|c|c|}
\hline Pavadoša intrakardiāla patoloğija & $\begin{array}{c}\text { Skaits (\% no visiem } 59 \\
\text { pacientiem) }\end{array}$ \\
\hline $\begin{array}{c}\text { Ventrikulu starpsienas defekts (VSD): } \\
\text { - perimembranozs VSD } \\
\text { - muskulārs VSD }\end{array}$ & $\begin{array}{c}10(17 \%) \\
7 \\
3 \\
\end{array}$ \\
\hline Ātriju starpsienas defekts (liels) & $1(2 \%)$ \\
\hline $\begin{array}{c}\text { Aortas stenoze (AoS) } \\
\text { Valvulāra AoS } \\
\text { Subvalvulāra AoS } \\
\text { Supravalvulāra AoS }\end{array}$ & $\begin{array}{c}7(12 \%) \\
3 \\
3 \\
1\end{array}$ \\
\hline Plaušu artērija stenoze (PS) + ASD & $1(2 \%)$ \\
\hline $\begin{array}{c}\text { Mitrālā vārstuḷa patoloǵija/nozīmīga } \\
\text { nepietiekamība }\end{array}$ & $1(2 \%)$ \\
\hline Mitrāla stenoze (MS) + VSD & $1(2 \%)$ \\
\hline
\end{tabular}

Pacienti novēroti 70,7 $\pm 33,4$ mēnešus (1 gadu 6 mēnešus līdz 11 gadus). Pētījuma periodā 10 pacientiem bijusi nepieciešama pavadošas intrakardiālas patoloǵijas ķirurǵiska korekcija vidēji $21 \pm 13,5$ mēnešu vecumā (nebija nepieciešama pavadoša patologijas ķirurğiska korekcija 84,7\% gadījumu (95\% TI 107,5-129,7 mēneši)). 


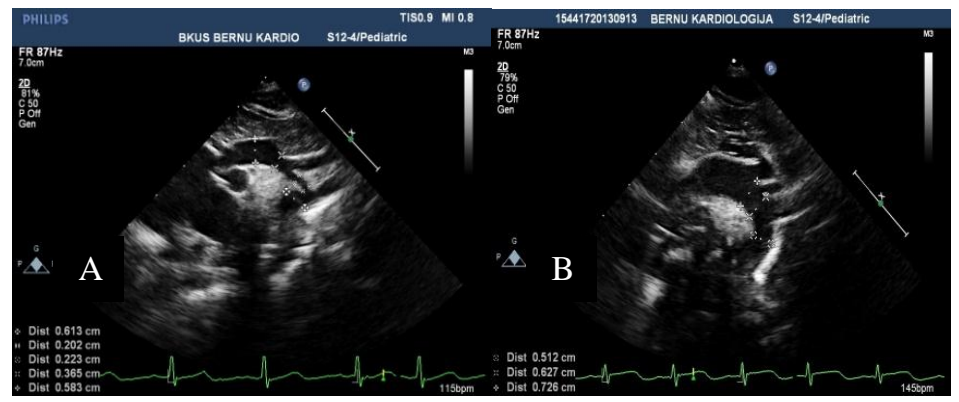

\section{6. att. A - AoCo un hipoplastisks Ao loks jaundzimušajam, B - normāls Ao loks veselam jaundzimušajam}

Ao rekoarktācijas zonas balonangioplastija BKUS uzsākta 2009. gada janvārī. Pētījuma periodā 15 no pētījuma grupas pacientiem konstatēta Ao rekoarktācija. Kumulatīva dzīvildze bez aortas rekoarktācijas pētījuma periodā bija 74,6\% gadījumu (95\% TI 89,6-118,1 mēnešus) (2.7. attēls).

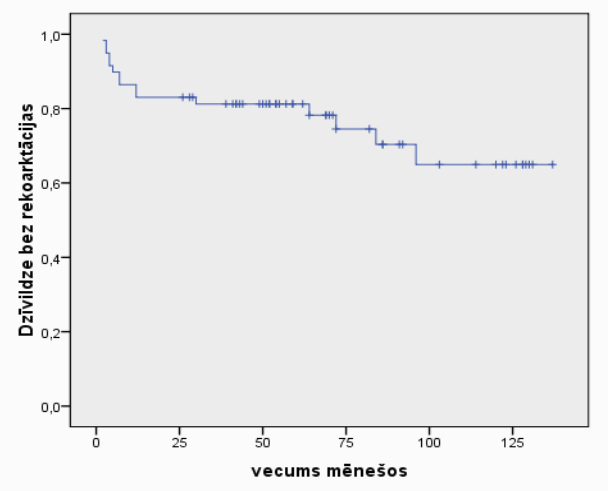

2.7. att. Kumulatīva dzīvildze bez rekoarktācijas pētījuma periodā

Angioplastijas brīdī pacienta vecums vidēji bija 35,7 $\pm 33,7$ mēneši ( 2 mēneši līdz 8 gadi). CWD Pg maks. descendējošā Ao bija $78 \pm 19$ mm Hg ar diastolisku komponenti plūsmas profilā (2.8. attēls). 
EHOKG atrade Ao rekoarktācijas brīdī un pētījuma perioda beigās salīdzinājumā ar veseliem kontroles grupas pacientiem sniegta 2.5. tabulā.

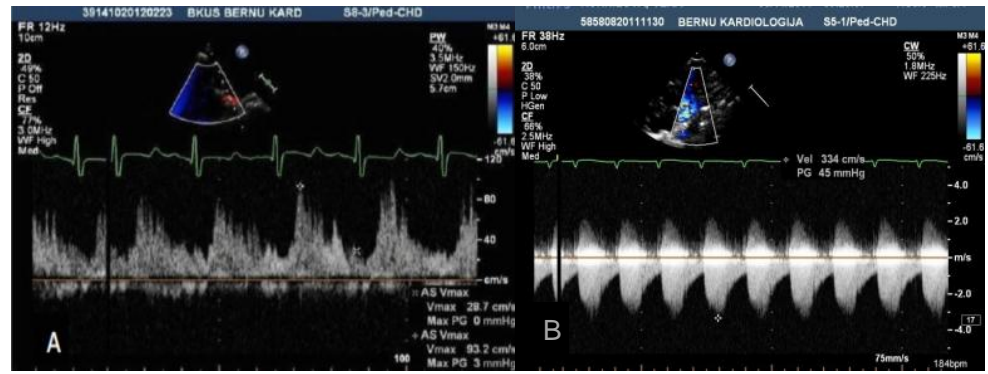

2.8. att. 3 mēnešus vecs zīdainis ar Ao rekoarktāciju: A - PWD plūsmas profils vēdera Ao - PWD S/D 3,2; B - CWD plūsmas profils descendējošā Ao (augsts spiediena gradients ar diastolisku komponenti)

Pētījuma perioda beigās pacientiem CWD Pg maks. descendējošā Ao bija $20 \pm 8,9$ mm Hg (95\% TI 17,6-22,4 mm Hg). Nevienam pacientam nebija nepieciešama transvazāla balonangioplastija. Pētījuma grupas pacientiem LVMi/augums $^{2,7}$ bija 42,49 7,07, mediāna 42,25 (95\% TI 40,39-44,59), kontroles grupā - 39,47 $\pm 7,04$, mediāna 40,35 (95\% TI 36,74-42,20), taču pacientiem pirms rekoarktācijas balonangioplastijas - 76,32 $\pm 19,88$, mediāna 71,70 (95\% TI 65,31-87,33) (2.9. attēls). Salīdzinot kreisā ventrikula masas indeksu pacientiem ar rekoarktāciju anamnēzē $\left(45,67 \pm 6,53 \mathrm{~g} / \mathrm{m}^{2,7}\right)$, bez aortas rekoarktācijas $\left(41,63 \pm 6,56 \mathrm{~g} / \mathrm{m}^{2,7}\right)$ un kontroles grupā $\left(39,47 \pm 7,04 \mathrm{~g} / \mathrm{m}^{2,7}\right)$, pacientiem pēc rekoarktācijas korekcijas tas saglabājās augstāks $(p=0,019)$, taču būtiski neatšksīās LVMi $z$ vērtības (Foster et al., 2008) $(p=0,087)$ (2.5. tabula). 

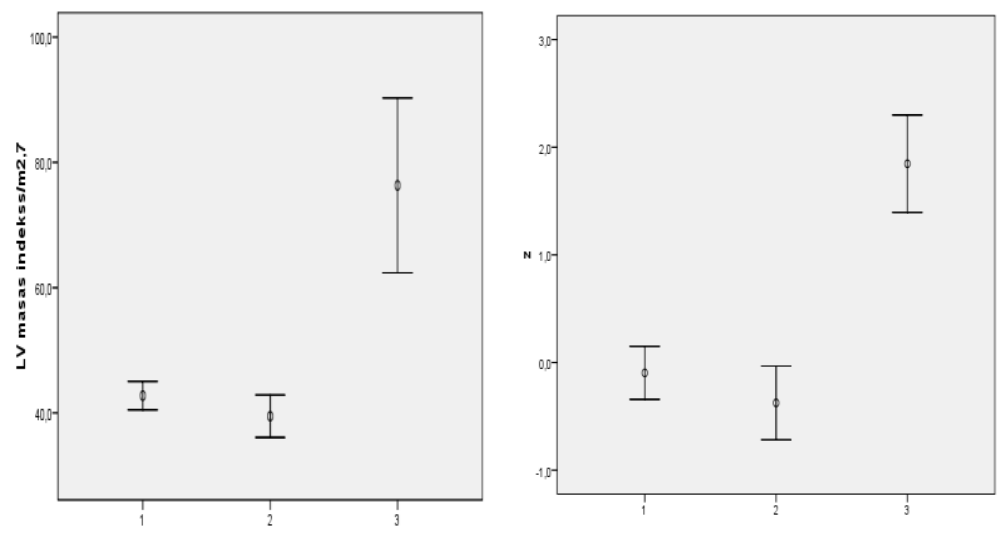

2.9. att. Kreisā ventrikula masas indeksa un kreisā ventrikula masas $z$ vērtību salīdzinājums

( 1 - pacienti pētījuma beigās, 2 - kontroles grupa, 3 - pacienti pirms rekoarktācijas balonangioplastijas)

Pacientiem no AoreCo balonangioplastijas bija pagājuši 21,1 $\pm 8,3$ mēneši. Pētījuma grupas pacientiem Ao transversā loka izmērs bija $12,43 \pm 1,81 \mathrm{~mm}$, bet kontroles grupā 13,36 $\pm 1,98 \mathrm{~mm} \quad(p=0,029)$, Ao transversā loka $z$ vērtība pētījuma grupā bija $-0,93 \pm 0,74$, bet kontroles grupā $-0,69 \pm 0,55(p=0,137)$. Statistiski neatšķīrās Ao transversā loka diametri visu anastomožu grupās: AGG 12,38 $\pm 2,34 \mathrm{~mm}$, IZA 12,35 $\pm 1,68 \mathrm{~mm}$ un PAGG $13,25 \pm 1,26 \mathrm{~mm} \quad(p=0,652)$. Ao isthmus daļa pētījuma grupā bija $9,31 \pm 1,55 \mathrm{~mm}$, taču kontroles grupā $-11,45 \pm 2,06 \mathrm{~mm}(p=0,0001)$. Ao isthmus $z$ vērtība pētījuma grupā bija $-0,74 \pm 0,76$, taču kontroles grupā šī vērtība bija $-0,01 \pm 0,67(p=0,0001)$. 
2.5. tabula

LVM, LVMi un PWD doplerogrāfiski mērījumi vēdera Ao pacientiem rekoarktācijas brīdī un pētîjuma perioda beigās salīdzinājumā ar kontroles grupu

* salīdzinājums starp kontroles grupu un pacientiem pētījuma perioda beigās ( $t$-tests)

\begin{tabular}{|c|c|c|c|c|}
\hline Parametri & $\begin{array}{c}\text { Pacienti } \\
\text { pētījuma } \\
\text { perioda } \\
\text { beigās } \\
(n=59)\end{array}$ & $\begin{array}{c}\text { Pacienti } \\
\text { pirms } \\
\text { AoreCo } \\
\text { balon- } \\
\text { dilatācijas } \\
(n=15)\end{array}$ & $\begin{array}{c}\text { Kontroles } \\
\text { grupa } \\
(n=28)\end{array}$ & $P$ vērtība \\
\hline Vecums (mēneši) & $73,17 \pm 34$ & $35,67 \pm 33$ & $69,96 \pm 36$ & $\begin{array}{c}* 0,69 \\
* * 0,005\end{array}$ \\
\hline $\operatorname{LVM}(\mathrm{g})^{1}$ & $57,76 \pm 21$ & $63,11 \pm 36$ & $61,34 \pm 25$ & $\begin{array}{c}* 0,51, \\
* * 0,85 \\
* * * 0,48\end{array}$ \\
\hline LVM $z$ vērtība ${ }^{1}$ & $-0,09 \pm 0,7$ & $1,85 \pm 0,64$ & $-0,37 \pm 0,71$ & $\begin{array}{c}* 0,091, \\
* * 0,0001 \\
* * * 0,0001\end{array}$ \\
\hline LVMi/augums $^{2,71}$ & $42,49 \pm 7,06$ & $76,32 \pm 19$ & $39,47 \pm 7,04$ & $\begin{array}{c}* 0,078, \\
* * 0,0001 \\
* * * 0,0001\end{array}$ \\
\hline PWD S Ao $(\mathrm{m} / \mathrm{s})$ & $0,87 \pm 0,24$ & $0,52 \pm 0,11$ & $0,93 \pm 0,22$ & $\begin{array}{c}* 0,31, \\
* * 0,0001, \\
* * * 0,0001\end{array}$ \\
\hline PWD D Ao $(\mathrm{m} / \mathrm{s})$ & $0,17 \pm 0,05$ & $0,25 \pm 0,11$ & $0,15 \pm 0,05$ & $\begin{array}{c}* 0,081, \\
* * 0,0001 \\
* * * 0,0001\end{array}$ \\
\hline PWD S/D & $5,25 \pm 1,18$ & $2,27 \pm 0,38$ & $6,31 \pm 1,41$ & $\begin{array}{c}* 0,001, \\
* * 0,0001 \\
* * * 0,0001\end{array}$ \\
\hline
\end{tabular}

** salīdzinājums starp kontroles grupu un pacientiem pirms AoreCo balonangioplastijas ( $t$-tests) *** salīdzinājums starp pacientiem pētījuma perioda beigās un pirms AoreCo balonangioplastijas ( $t$-tests)

${ }^{1}$ LVM, LVM $z$ vērtība, LVMi/augums ${ }^{2,7}$ pētījuma grupā rēķināts pacientiem bez AoS un MV patologijas $(n=49)$ 


\subsection{Aortas loka biomehāniskās īpašības jaundzimušajiem un zīdaiṇiem dažādu AoCo ķirurğiskai ārstēšanai izmantotu anastomožu gadījumā}

Biomehānisko eksperimentu rezultātā novērota jaundzimušo un zīdaiņu aortas nelineāra sakarība starp spiedienu un deformāciju (2.10. attēls).

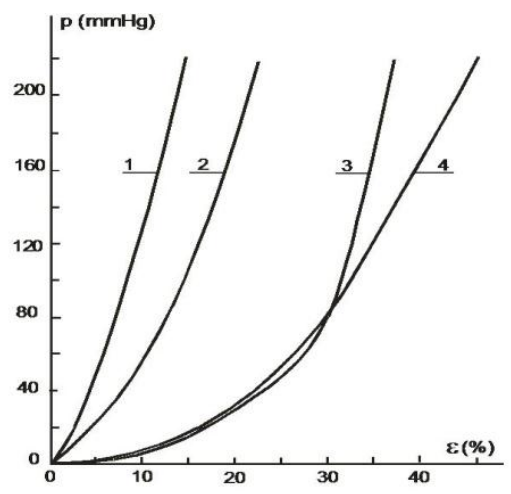

2.10. att. Sakarība starp spiedienu un deformāciju: 1 - anastomoze gals-galā (AGG), 2 - pagarināta anastomoze gals-galā (PAGG), 3 - ielāps ar kreisās zematslēgas artērijas lēveru (IZA), 4 - natīva aorta

Paraugu sieniņas biezums bija 1,1 $\pm 0,1 \mathrm{~mm}$ (minimāli 0,91 mm, maksimāli 1,26 mm, mediāna 1,13 mm, moda 1,06 mm). Aortas deformācija pie iekšējā spiediena $60 \mathrm{~mm} \mathrm{Hg}$ bija $25,12 \pm 9,37 \%$, pie $80 \mathrm{~mm} \mathrm{Hg}$

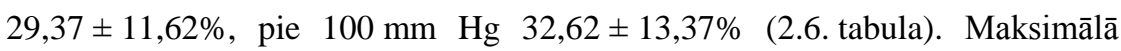
deformācija pie iekšèjā spiediena 220 mm Hg bija 47,65 \pm 15,41\%. Natīvas Ao spriegums pie iekšèjā spiediena $60 \mathrm{~mm} \mathrm{Hg}$ bija 45,32 $\pm 15,29 \mathrm{kPa}$, pie $80 \mathrm{~mm}$ $\mathrm{Hg}-65,36 \pm 24,2 \mathrm{kPa}$, pie $100 \mathrm{~mm} \mathrm{Hg}-86,31 \pm 33,54 \mathrm{kPa}$, bet pie $220 \mathrm{~mm}$ Hg spriegums bija attiecīgi 253,41 $\pm 95,94 \mathrm{kPa}$ (2.7. tabula). Būtiskuma līmenis $p$ atšķirībām starp dažādiem paraugiem sniegts 2.8. un 2.9. tabulā. 
Ao sieniṇas deformācija pie dažāda iekšējā spiediena natīvas Ao, AGG, IZA, PAGG gadījumā

\begin{tabular}{|c|c|c|c|c|}
\hline Paraugs & $\begin{array}{c}\boldsymbol{\varepsilon}(\boldsymbol{\%}) \\
\mathbf{6 0} \mathbf{~ m m} \mathbf{H g}\end{array}$ & $\begin{array}{c}\boldsymbol{\varepsilon}(\boldsymbol{\%}) \\
\mathbf{8 0} \mathbf{~ m m} \mathbf{H g}\end{array}$ & $\begin{array}{c}\boldsymbol{\varepsilon}(\boldsymbol{\%}) \\
\mathbf{1 0 0} \mathbf{~ m m} \mathbf{H g}\end{array}$ & $\begin{array}{c}\boldsymbol{\varepsilon}(\boldsymbol{\%}) \\
\mathbf{1 2 0} \mathbf{~ m m} \mathbf{~ H g}\end{array}$ \\
\hline Natīva Ao & $25,12 \pm 9,37$ & $29,37 \pm 11,62$ & $32,62 \pm 13,37$ & $34,93 \pm 14,43$ \\
\hline IZA & $26,41 \pm 67,25$ & $28,87 \pm 6,29$ & $30,62 \pm 6,26$ & $31,91 \pm 6,20$ \\
\hline PAGG & $10,01 \pm 1,59$ & $12,25 \pm 1,73$ & $14,06 \pm 2,05$ & $15,77 \pm 2,38$ \\
\hline AGG & $4,83 \pm 1,22$ & $6,33 \pm 1,29$ & $7,63 \pm 1,22$ & $8,9 \pm 1,40$ \\
\hline
\end{tabular}

Anastomozes gals-galā (AGG) gadījumā sakarība starp spriegumu un deformāciju bija lineāra (2.9. attēls.). AGG deformācija mazinājās un pie iekšējā spiediena $60 \mathrm{~mm} \mathrm{Hg}$ bija 4,83 $\pm 1,22 \%$, pie $80 \mathrm{~mm} \mathrm{Hg}-6,33 \pm 1,29 \%$, pie 100 mm Hg - 7,63 \pm 1,22\%. Šuvju vietā maksimālā deformācija pie iekšējā spiediena $220 \mathrm{~mm} \mathrm{Hg}$ sasniedza tikai 15,78 $\pm 3,09 \%$. Salīdzinot ar natīvas aortas deformāciju, redzams, ka AGG deformējās krietni mazāk, taču, salīdzinot ar aortas deformāciju pie iekšējā spiediena $220 \mathrm{~mm} \mathrm{Hg}$, AGG deformācija bija divas reizes mazāka. Ielāpa ar kreisās zematslēgas artērijas lēveru (IZA) gadījumā deformācija pie iekšējā spiediena $60 \mathrm{~mm} \mathrm{Hg}$ bija $26,41 \pm 67,25 \%$, pie $80 \mathrm{~mm} \mathrm{Hg}-28,87 \pm 6,29 \%$, pie $100 \mathrm{~mm} \mathrm{Hg}-$ $30,62 \pm 6,26 \%$. Maksimālā deformācija pie iekšējā spiediena $220 \mathrm{~mm} \mathrm{Hg}$ sasniedza $37,73 \pm 7,86 \%$, kas ir salīdzinoši vistuvāk natīvas aortas biomehāniskajām īpašībām. Pagarinātas anastomozes gals-galā (PAGG) gadījumā deformācija pie iekšējā spiediena 60 mm Hg bija 10,01 $\pm 1,59 \%$, pie $80 \mathrm{~mm} \mathrm{Hg}-12,25 \pm 1,73 \%$, pie $100 \mathrm{~mm} \mathrm{Hg}-14,06 \pm 2,05 \%$. Maksimālā deformācija pie iekšējā spiediena 220 mm Hg sasniedza 22,57 2,85\%, kas 2 reizes pārsniedza deformāciju perpendikulāras cirkulāras šuves jeb AGG gadījumā, taču, salīdzinot ar IZA, atpalika no natīvas aortas un IZA. 
2.7. tabula

Ao sieniņas spriegums pie dažāda iekšējā spiediena natīvas Ao, AGG, PAGG un IZA gadījumā

\begin{tabular}{|c|c|c|c|c|}
\hline Paraugs & $\begin{array}{c}\boldsymbol{\sigma}(\mathbf{k P a}) \\
\mathbf{6 0} \mathbf{~ m m ~ H g}\end{array}$ & $\begin{array}{c}\boldsymbol{\sigma} \mathbf{( k P a}) \\
\mathbf{8 0} \mathbf{~ m m ~ H g}\end{array}$ & $\begin{array}{c}\boldsymbol{\sigma}(\mathbf{k P a}) \\
\mathbf{1 0 0} \mathbf{~ m m} \mathbf{H g}\end{array}$ & $\begin{array}{c}\boldsymbol{\sigma}(\mathbf{k P a}) \\
\mathbf{1 2 0} \mathbf{~ m m} \mathbf{H g}\end{array}$ \\
\hline Natīva Ao & $45,32 \pm 15,29$ & $65,36 \pm 24,20$ & $86,31 \pm 33,54$ & $108,04 \pm 42,72$ \\
\hline IZA & $35,99 \pm 7,58$ & $51,10 \pm 1,79$ & $65,09 \pm 2,91$ & $78,35 \pm 6,81$ \\
\hline PAGG & $39,32 \pm 3,49$ & $54,44 \pm 4,74$ & $70,11 \pm 6,28$ & $86,66 \pm 7,93$ \\
\hline AGG & $36,15 \pm 2,85$ & $49,52 \pm 4,01$ & $63,41 \pm 7,28$ & $78,35 \pm 6,81$ \\
\hline
\end{tabular}

Aortas sieniṇas elastības modulis palielinājās, pieaugot iekšējam spiedienam (2.8. tabula). Pie iekšējā spiediena starp 60-80 mm Hg elastības modulis bija $516,08 \pm 126,21 \mathrm{kPa}$, bet pie spiediena $100-120 \mathrm{~mm} \mathrm{Hg}$ elastības modulis palielinājās līdz 967,45 $\pm 164,60$ kPa (vairāk nekā 2 reizes).

AGG gadījumā elastības modulis bija praktiski konstants, un pie spiediena $60-80 \mathrm{~mm} \mathrm{Hg}$ tas bija $1138,08 \pm 216,23 \mathrm{kPa}$, bet pie spiediena $100-$ 120 mm Hg elastības modulis pieauga līdz 1261,35 $\pm 235,76 \mathrm{kPa}$.

Elastības modulis AGG gadījumā pie iekšējā spiediena 60-80 mm Hg bija tuvu natīvas aortas sieniņas elastības modulim pie iekšējā spiediena 100120 mm Hg. Rezultāti liecina, ka AGG stingums minimāli mainās, mainoties iekšējam spiedienam, kas var ietekmēt hemodinamiku. PAGG gadījumā elastības modulis pie spiediena $60-80 \mathrm{~mm} \mathrm{Hg}$ bija $683,29 \pm 65,87 \mathrm{kPa}$, bet pie spiediena $100-120 \mathrm{~mm} \mathrm{Hg}$ tas bija $1232,79 \pm 586,79 \mathrm{kPa}$. IZA gadījumā elastības modulis pie spiediena $60-80 \mathrm{~mm} \mathrm{Hg}$ bija $615,95 \pm 50,88 \mathrm{kPa}$, bet pie spiediena 100-120 mm Hg - 1158,35 =127,52 kPa, kas salīdzinoši ir vistuvāk natīvas aortas biomehāniskajām īpašībām. 
2.8. tabula

Natīvas Ao, AGG, PAGG un IZA elastības modulis dažāâ iekšējā spiediena gadījumā

\begin{tabular}{|c|c|c|c|}
\hline Paraugs & $\begin{array}{c}\mathbf{E}(\mathbf{k P a}) \\
\mathbf{6 0}-\mathbf{8 0} \mathbf{~ m m} \mathbf{~ H g}\end{array}$ & $\begin{array}{c}\mathbf{E}(\mathbf{k P a}) \\
\mathbf{8 0}-\mathbf{1 0 0} \mathbf{~ m m} \mathbf{~ H g}\end{array}$ & $\begin{array}{c}\mathbf{E}(\mathbf{k P a}) \\
\mathbf{1 0 0}-\mathbf{1 2 0} \mathbf{~ m m} \mathbf{~ H g}\end{array}$ \\
\hline Natīva Ao & $516,08 \pm 126,21$ & $704,02 \pm 170,67$ & $967,45 \pm 164,60$ \\
\hline IZA & $615,95 \pm 50,88$ & $798,46 \pm 25,26$ & $1158,35 \pm 127,52$ \\
\hline PAGG & $683,29 \pm 65,87$ & $932,63 \pm 257,18$ & $1232,79 \pm 586,79$ \\
\hline AGG & $902,39 \pm 86,49$ & $1138,16 \pm 216,23$ & $1261,35 \pm 235,76$ \\
\hline
\end{tabular}

2.9. tabula

Būtiskuma līmenis $p$ atšķirībām starp dažādu paraugu deformācijām

\begin{tabular}{|c|c|c|c|}
\hline Paraugi & $\mathbf{\varepsilon} \boldsymbol{\%}(\mathbf{8 0} \mathbf{~ m m}$ & $\boldsymbol{\varepsilon} \boldsymbol{\%}(\mathbf{1 0 0} \mathbf{~ m m}$ & $\mathbf{\varepsilon} \% \mathbf{\%}(\mathbf{1 2 0} \mathbf{~ m m}$ \\
& $\mathbf{H g})$ & $\mathbf{H g})$ & $\mathbf{H g})$ \\
\hline Ao/ IZA & $p=0,476$ & $p=0,404$ & $p=0,366$ \\
\hline Ao / PAGG & $p=0,015$ & $p=0,0125$ & $p=0,0137$ \\
\hline Ao / AGG & $p=0,0079$ & $p=0,0064$ & $p=0,0067$ \\
\hline IZA / PAGG & $p=0,0058$ & $p=0,006$ & $p=0,0068$ \\
\hline PAGG / AGG & $p=0,0094$ & $p=0,0063$ & $p=0,0082$ \\
\hline
\end{tabular}


2.10. tabula

Būtiskuma līmenis $p$ atšksirībām starp dažādu paraugu elastības moduliem

\begin{tabular}{|c|c|c|c|}
\hline Paraugi & $\begin{array}{c}\mathbf{E} \mathbf{~ k P a} \\
(\mathbf{6 0}-\mathbf{8 0} \mathbf{~ m m} \mathbf{H g})\end{array}$ & $\begin{array}{c}\mathbf{E} \mathbf{~ k P a} \\
(\mathbf{8 0}-\mathbf{1 0 0} \mathbf{~ m m} \mathbf{H g})\end{array}$ & $\begin{array}{c}\mathbf{E} \mathbf{~ k a} \\
(\mathbf{1 0 0}-\mathbf{1 2 0} \mathbf{~ m m} \mathbf{H g})\end{array}$ \\
\hline Ao / IZA & $p=0,113$ & $p=0,379$ & $p=0,358$ \\
\hline Ao / PAGG & $p=0,021$ & $p=0,173$ & $p=0,3$ \\
\hline Ao / AGG & $p=0,0006$ & $p=0,044$ & $p=0,25$ \\
\hline IZA / PAGG & $p=0,168$ & $p=0,275$ & $p=0,441$ \\
\hline PAGG / AGG & $p=0,022$ & $p=0,227$ & $p=0,478$ \\
\hline
\end{tabular}




\section{DISKUSIJA}

Iegūtie dati par parāda, ka AoCo prevalence Latvijā jaundzimušajiem neatšķiras no citu Eiropas valstu datiem. AoCo ir grūti diagnosticējama prenatāli, jo š̄ sirdskaite hemodinamiski pilnībā izveidojas tikai pēc dzimšanas, slēdzoties arteriālam vadam. Pētījumā par VCC antenatālu diagnostiku Khoshnood B. et al. (2005) pierādīja AoCo prenatālas diagnostikas palielināšanos līdz 40\%. Pēc Matsui H. un Mellander M. (2008) datiem, 32\% gadījumu zīdaiṇiem ar izolētu AoCo, kas stacionēti tās ķirurǵiskajai korekcijai, aizdomas par VCC bija izteiktas antenatāli. Jāsecina, ka biežāk antenatāli tiek diagnosticēti smagākie gadījumi, kas kombinējas ar pavadošu intrakardiālu patologiju.

Pētījuma dati parāda, ka 36\% jeb trešā daļa zīdaiņu ar AoCo tika nosūtîti ārstēšanai tikai pēc izrakstǐšanas mājās no dzemdību iestādes, ceturtajā dal̦ā (27\%) gadījumu ārstam neaizdomājoties par VCC kā bērna stāvokḷa pasliktināšanās tiešo cēloni. Agrīna nosūtī̌sana korelēja ar citas pavadošas intrakardiālas anomālijas esamību, kas, izklausot troksni uz sirds un/vai konstatējot kardiovaskulāras mazspējas pazīmes, palīdzēja ātrāk atpazīt VCC. Izolētas AoCo gadījumā pusei pacientu diagnoze noteikta, nokḷūstot stacionārā pēc izrakstīšanās mājās no dzemdību iestādes.

Aamir T. et al. (2007) aprakstīja AoCo kā biežāko nozīmīgo vēlīni diagnosticēto VCC zīdaiņiem, kad pacienta vecums galīgās diagnozes noteikšanas brīdī bija no 3 dienām līdz pat 6 mēnešiem (vidēji 6 nedēḷas). Aprakstītajiem jaundzimušajiem un zīdaiņiem pirms galīgās diagnozes noteikšanas bija noteiktas dažādas citu slimību diagnozes, 40\% gadījumu šie bērni nokḷuva intensīvās terapijas nodaḷā.

Aprēķināts, ka universāla skrīninga ehokardiogrāfija visiem jaundzimušajiem būtu pārāk dārga un ne tik efektīva metode, ņemot vērā 
tranzitoras hemodinamiskas izmaiņas agrīnā neonatālā periodā. Pēdējo gadu laikā pētnieki ieteikuši pulsa oksimetriju kā klīniskās izmeklēšanas papildmetodi no arteriāla vada atkarīgu sirdskaišu agrīnai noteikšanai jaundzimušajiem. De-Wahl Granelli A. et al. (2009) ieteica preduktālas (labā roka) un postduktālas (kāja) saturācijas mērījumus jaundzimušo skrīningam, lai izslēgtu nozīmīgas no arteriāla vada atkarīgas sirdskaites. Par skrīninga pozitīviem šajā gadījumā uzskatāmi bērni ar saturāciju zem 95\% trīs atkārtotos mērījumos.

Šì metode diemžēl nav pietiekami efektīva no arteriāla vada atkarīgas sistēmiskas cirkulācijas diagnosticēšanai. Citā pētījumā De-Wahl Granelli A. un Östman-Smith A. (2007) iesaka izmantot neinvazīva perifērās perfūzijas indeksa mērījumus (PPI) labajā rokā (preduktāli) un kājā (postduktāli). Preduktāli vai postduktāli iegūts PPI zem 5. procentiles (zem vērtības 0,7$)$ būtu izmantojams kā robežvērtība kreisās puses obstruktīvu sirdskaišu diagnostikā jaundzimušajiem. Kombinācijā ar fizikālu izmeklēšanu, ieverot femorāla pulsu palpāciju visiem jaundzimušajiem un pulsoksimetriju, tā būtu izmantojama kā skrīninga metode dzemdību iestādēs, veicot ehokardiogrāfiju skrīninga pozitīvajiem pacientiem.

Femorālā pulsa palpācija Latvijā iekḷauta vesela jaundzimušā medicīniskās aprūpes vadlīnijās ārsta pirmajā apskatē 24 stundu laikā pēc dzimšanas (Latvijas Neonatologu biedrība, 2010), tomēr tā nav iekḷauta jaundzimušā kardiovaskulārās sistēmas izmeklēšanas protokolā kā obligāta izrakstīšanās brīdī no dzemdību iestādes, kā arī jaundzimušo apskatē ǵimenes ārstam. Lielākajai daḷai jaundzimušo, slēdzoties arteriālam vadam, vājš vai nepalpējams femorālais pulss sākotnēji var būt vien̄̄gā aortas koarktācijas raksturīgā pazīme. Ja femorāla pulsa palpāciju neveic, mazinās iespējas konstatēt sirdskaites, kas nosaka no arteriāla vada atkarīgu sistēmisku cirkulāciju. 
Aortas koarktācija jaundzimušo un zīdaiņu vecumā pēdējā desmitgadē joprojām saistîta ar augstu mirstību, ko ietekmē tādi faktori kā pacienta perioperatīvais stāvoklis, asociētas intrakardiālas patologijas, aortas loka hipoplāzija, perioperatīva intensīva terapija. Grupā ar izolētu AoCo pētījuma perioda beigās dzīvi 95\% pacientu pretstatā 59 un 67\% grupās ar VSD un citām pavadošām intrakardiālām patoloǵijām $(p=0,001)$. Kopumā izdzīvotība pētījuma perioda beigās bija $81 \%$. Hoimyr H. et al. (2006, Dānija) pētījums ar vienu no ilgstošākajiem novērojumiem 40 gadu garumā (vidēji 29 gadi), kurā no 229 pacientiem ietverti tikai 8\% bērni vecuma grupā līdz 1 gadam, parāda kopējo izdzīvotību 69\%. Pacienti bez asociētām sirdskaitēm, kuri veiksmīgi pārdzīvoja sirdskaites ķirurǵisku korekciju, bija paḳ̦auti 3,4 reizes augstākai mirstībai un saslimstībai ilgtermiņā nekā to vienaudži populācijāa ķirurğiskai metodei nebija būtiskas nozīmes. Kaushal S. et al. (2009, ASV) pētījumā, kurā AoCo koriǵēta, izmantojot PAGG 201 pacientam, taču nav iekḷauti pacienti ar kompleksu AoCo, kopējā mirstība bija 4\% (novērojums vidēji 4,3 gadi). Barreiro C. J. et al. (2007, ASV) pētījumā ar 119 zīdaiņiem, kuriem koriǵēta izolēta AoCo, kopējā mirstība bija 10\%.

Aortas koarktācijas gadījumā jaundzimušajiem un zīdaiņiem ir augsta AoreCo incidence (25\%). Rekoarktāciju biežums būtiski neatšķīrās dažādu ķirurǵiskas ārstēšanas metožu gadījumā. Literatūrā aprakstīta Ao rekoarktācijas incidence pacientiem, kuri operēti jaundzimušo un zīdaiņu vecumā 7-29\% gadījumu. Karamlau T. et al. (2009, Kanāda) apraksta rekoarktāciju biežumu 14\% zīdaiņu, kuriem izolēta AoCo koriğēta 2-69 dienu vecumā. Sudarshan C. D. et al. (2006, Austrālija) apraksta rekoarktāciju 29\% jaundzimušo, kuru svars operācijas brīdī bijis līdz 2 kg. Hager A. et al. (2009,Vācija) apraksta AoreCo 24\% zīdaiņu ar izolētu AoCo. Fruh S. et al. (2011, Šveice) apraksta AoreCo 11\% jaundzimušo ar AoCo korekciju 0-6 mēnešu vecumā, taču Fiore A. et al. (2005, ASV) novēro AoreCo 18\% zīdainu ar AoCo korekciju vecumā līdz 40 dienām. Mūsu klīnikas pacientiem vairāk nekā pusē gadījumu (60\%) 
rekoarktācija attīstìjās pirmā gada laikā pēc sirdskaites ķirurǵiskas korekcijas. Kaushal S. et al. (2009, ASV) 75\% gadījumu apraksta AoreCo attīstību pirmā gada laikā pēc AoCo ķirurğiskas ārstēšanas.

Literatūras dati apstiprina, ka ķirurğiska korekcija ir pamatmetode AoCo ārstēšanai jaundzimušajiem un zīdainiem sakarā ar mazāku reintervences nepieciešamību pēc AoCo ķirurǵiskas korekcijas un mazāku komplikāciju attīstības risku (Kenny et Hijazi, 2011; Fiore et al., 2005; Fruh et al., 2011; Peres et al., 2010). Aortas koarktācija ķirurğiskas korekcijas svarīgākais mērķis un pamatmērķis ir adekvāta aortas loka rekonstrukcija, kam seko citu asociēto sirds strukturālo anomāliju secīga korekcija. Dažādu ķirurǵiskas ārstēšanas metožu lietošanas gadījumā rekoarktācijas attīstības mehānismi ir atškirīgi. AGG gadījumā rekoarktācijas veidošanos saista ar neadekvātu arteriāla vada audu rezekciju un cirkulāras šuvju līnijas traucētu augšanu, IZA gadījumā ar arteriāla vada audu nepilnīgu ekscīziju. Agrīna restenoze pēc balonangioplastijas jaundzimušajiem var būt saistîta ar koarktācijas zonu apņemošo ductus arteriosus audu elastīgu konstrikciju. Balondilatācija un/vai stenta implantācija kā izvēles metode ar labiem rezultātiem AoCo korekcijai rekomendēta vecākiem bērniem un Ao rekoarktācijas gadījumā (Golden et Hellebrand, 2007; Kenny et Hijazi, 2011; Reich et al., 2008; Rodes-Cabau et al., 2007).

Aortas rekoarktācijas brīdī pacientiem tika ehokardiogrāfiski novērota kreisā ventrikula hipertrofija, kas dinamikā izzuda pēc stenozes korekcijas, taču kreisā ventrikula masas indekss (LVMi/augums ${ }^{2,7}$ ) pētîjuma beigās bija lielāks salīdzinājumā ar kontroles grupas pacientiem un pacientiem bez rekoarktācijas anamnēzē. Par kreisā ventrikula hipertrofiju pieaugušajiem runā, ja LVMi/augums ${ }^{2,7}$ pārsniedz $51 \mathrm{~g} / \mathrm{m}^{2,7}$ (De Simone et al., 1995). Foster B. J. et al. (2008) aprakstījuši tādu pašu LVMi/augums ${ }^{2,7}$ vērtību kā 95. procentili veseliem bērniem bez būtiskas dzimumu atšķirības līdz 12 gadu vecumam. Daniels S. R. et al. (1995) ziņojuši par $38,6 \mathrm{~g} / \mathrm{m}^{2,7} \mathrm{kā} 95$. procentili veselu 
bērnu populācijā. Khoury P. R. et al. (2009) noskaidroja, ka bērniem, kuri jaunāki par 9 gadu vecumu, LVMi/augums ${ }^{2,7}$ atšksiras atkarībā no pacienta vecuma. Jaundzimušajiem un zīdaiņiem LVMi/augums ${ }^{2,7}$ bija aptuveni divas reizes lielāks nekā vecākiem bērniem un pusaudžiem: 95. procentile jaundzimušajiem bija $80 \mathrm{~g} / \mathrm{m}^{2,7}$, bet 11 gadus veciem bērniem $-40 \mathrm{~g} / \mathrm{m}^{2,7}$. Kreisā ventrikula hipertrofija kombinācijā ar arteriālu hipertensiju ir kardiovaskulārs riska faktors, kas palielina miokarda infarkta, insulta un nāves risku, taču var tikt modificēts (Bauml, 2010). Zīdaiņi un mazi bērni regulāri jānovēro ambulatori pēc AoCo ķirurǵiskas korekcijas, lai izslēgtu iespējamu AoreCo veidošanos un nepieciešamību pēc transvazālas korekcijas.

Novērojuma grupas EHOKG protokols tika papildināts ar PWD doplerogrāfisku mērījumu analīzi vēdera Ao. Ehokardiogrāfija mūsdienās uzskatāma par primāru neinvazīvu metodi AoCo un AoreCo diagnostikā. AoCo un AoreCo klīniskas smaguma pakāpes stratifikācija balstīta uz spiediena gradienta mērījumiem, klīniskiem simptomiem un lūmena sašaurinājuma pakāpes noteikšanu. Suboptimāls CWD doplera stara centrējums attiecībā pret plūsmas virzienu var būt par iemeslu koarktācijas patiesās smaguma pakāpes nenovērtēšanai. Silvilairat S. et al. (2008), analizējot PWD plūsmas profilu vēdera Ao pacientiem pēc AoCo ķirurǵiskas korekcijas, konstatēja, ka sistoliskas/diastoliskas plūsmas attiecība (PWD S/D) $<3,6$ raksturīga klīniski nozīmīgai AoCo. Autores veiktajā pētījumā pacientiem ar nozīmīgu AoreCo šī attiecība bija būtiski samazināta, kas saskan ar iepriekš aprakstīto. Pulsa viļ̣na doplerogrāfiski mērījumi abdominālā Ao diafragmas līmenī viegli veicami un kalpo kā papildu informācija nepārtraukta viḷna (CWD) doplerogrāfiskiem mērījumiem descendējošā Ao, lai apstiprinātu rekoarktāciju.

Lēmums par ķirurǵiskas korekcijas vai atkārtotas iejaukšanās laiku un lietojamo metodiku parasti atkarīgs no detalizētiem Ao loka un sirds struktūru mērījumu rezultātiem. Liu J. Y. J. et al. (2010) aprakstīja korelāciju starp proksimālā Ao loka izmēru EHOKG pēdējās novērojuma vizītes laikā un šo 
izmēru pirms ķirurgisiskas korekcijas un lietoto ķirurǵgisko metodiku. Trešdaḷai šo pacientu joprojām novērots šaurs proksimālais Ao loks. BKUS veiktajā pētījumā proksimālā transversā Ao loka $z$ vērtības pētîjuma beigās kopumā statistiski neatšķīrās no kontroles grupas pacientiem, taču joprojām 5 pacientiem $z$ vērtība bija $-2,28 \pm 0,15$ ar spiediena gradientu descendējošā Ao CWD Pg maks. 15,2 $\pm 5,8 \mathrm{~mm} \mathrm{Hg}$. Četriem no šiem pacientiem bija veikta ķirurğiska korekcija, izmantojot IZA, taču 1 gadījumā - AGG. Aprakstītajiem pacientiem netika novērota arteriāla hipertensija pētījuma perioda beigās, tomēr tie varētu būt uzskatāmi par riska grupas pacientiem arteriālas hipertensijas attīstībai nākotnē. Iespējamas atšķirīgas Ao loka paplašināšanas iespējas starp dažādām ķirurğiskām metodikām un operējošiem ķirurgiem. Būtu nepieciešami papildu pêtījumi, lai izvērtētu rezultātus, operējot šādus pacientus pieejā no mediānas sternotomijas un lietojot paplašinātu Ao loka plastiku, jo hipoplastiska proksimālā transversā Ao loka remodelācija, pacientam pieaugot, var nenotikt pēc konvencionālas Ao loka plastikas pacientiem ar vidēji un viegli hipoplastiskiem Ao lokiem (Liu et al., 2010; Rakhra et al., 2013; Sakurai et al., 2012).

Arī iepriekš veiktie anatomiskie pētījumi pierāda, ka vidējie transversā aortas loka un isthmus daļas diametri pacientiem ar diskrētu koarktāciju ir būtiski mazāki nekā veseliem indivīdiem šajā pašā vecumā ar identisku ķermeña laukumu un atrodas uz 15.-18. procentiles. BKUS pacientu dati liecina, ka pētījuma grupas pacientiem bez klīniski nozīmīgas AoreCoAo isthmus daļa ir būtiski šaurāka nekā kontroles grupas pacientiem $(p=0,0001)$. Puranik $R$. et al. (2009) magnētiskās rezonanses pētījumā ar pacientiem 20 gadus pēc ķirurğiskas AoCo primāras korekcijas līdz 2 gadu vecumam konstatēja nozīmīgas rekoarktācijas (34\% vieglas pakāpes un 34\% vidēji izteiktu līdz pat smagas pakāpes AoreCo). Autori rekomendēja biežu neinvazīvu izmeklēšanu kombinācijā ar klīnisku izmeklēšanu un MRI kā finansiāli visizdevīgāko stratēgiju pacientiem pēc AoCo ķirurgískas korekcijas. 
Artērijas sieniņas stingums aprakstīts kā neatkarīgs kardiovaskulāro notikumu, akūta koronārā sindroma, intrakraniālas hemorāgijjas un mirstības riska faktors (Bassareo et al., 2009; Ou et al., 2008). Atkārtoti klīniski pētījumi pierādījuši, ka normotensīviem indivīdiem pēc aortas koarktācijas korekcijas ir būtiski paaugstināts aortas stingums un samazināta elasticitāte, paaugstināts pulsa viḷna ātrums ehokardiogrāfijas un magnētiskās rezonanses izmeklējumos, kas noved pie kreisā ventrikula masas pieauguma, neskatoties uz veiksmīgu sirdskaites ķirurğisku korekciju. Pētījuma dati pierāda, ka pastāv būtiskas atšķirības starp natīvas aortas un aortas ar dažādu ķirurǵisku korekciju biomehāniskajām īpašībām. Jaundzimušā un zīdaiṇa natīvai aortai piemīt lielas deformācijas spējas, kas izskaidro literatūrā atspoguḷoto augsto rekoarktācijas incidenci pēc primāras balonangioplastijas agrīna vecuma bērniem. Natīvas aortas sieniņas elastības modulis pieaug, pieaugot iekšējam spiedienam, bet dažādu ķirurğisku korekciju gadījumā šīs izmaiņas ir ierobežotas. Šuvju apvidū novēro daudz mazāku deformāciju. Fiziolog̣iska arteriāla spiediena robežās miera stāvoklī vērojama mazāka diference starp natīvas aortas un ķirurǵiski koriǵētas aortas biomehāniskajām īpašībām, taču atšķirības kḷūst daudz izteiktākas, pieaugot iekšējam spiedienam. Vislielākās atšķirības novērotas anastomozes gals-galā gadījumā, kas saistāmas ar cirkulāras šuvju līnijas esamību. Salīdzinoši mazākas atšķirības novērotas pagarinātas anastomozes gals-galā gadījumā, vistuvāk natīvai aortai bija anastomoze ar zematlēgas artērijas lēveru. Šī atrade sakrīt ar datiem, ka pacientiem pēc veiksmīgas AoCo ķirurǵiskas korekcijas, kas miera stāvoklī uzskatāmi par normotensīviem, novērots straujš arteriālā spiediena pieaugums fiziskas slodzes apstākḷıs.

Veiktajā pētījumā biomehānisko eksperimentu rezultāti iegūti in vitro pētījumos, kas var būt par cēloni atšķirīibām no pacientiem in vivo. Pētījuma ierobežojumi ir salīdzinoši nelielais eksperimentu skaits, kā arī tas, ka in vitro eksperimenta laikā slogošanas procesā tiek uzturēts konstants longitudināls iestiepums, kas nav uzskatāms par pilnībā fiziologisku. 
Salīdzinot biomehānisko pētījumu rezultātus ar EHOKG atradi agrīnā pēcoperācijas periodā aprakstītajiem BKUS pacientiem, konstatēts, ka tie sakrīt ar spiediena gradienta mazināšanos agrīni postoperatīvi dažāasas operāciju metodikas gadījumā: AGG CWD Pg maks. 25,53 \pm 9,4 mm Hg, PAGG $17,64 \pm 4,5 \mathrm{~mm} \mathrm{Hg}$, bet IZA 15,95 $\pm 6,6$. Tomēr ilglaicīgu novērojumu rezultāti neparādīja statistiski ticamas AoreCo attīstības biežuma atšķirības dažādu anastomožu lietošanas gadījumā. AoreCo novērota 18\% AGG grupā, $29 \%$ IZA grupā un 25\% PAGG grupā ( $p=0,67)$. IZA priekšrocības varētu būt salīdzinoši mazāks iestiepums šuvju vietās, iespēja izvairīties no cirkulāras šuves un autologu audu augšanas potenciāls, taču trūkums ir nepieciešamība ziedot kreiso zematslēgas artēriju, tāpēc daudzos centros priekšroka tiek dota PAGG gadījumos, kad pacientam novēro infantilu AoCo ar isthmus un reizēm transversā Ao loka hipoplāziju. Reinhart Z. et al. (2012, Lielbritānija) apraksta zemāku rekoarktācijas incidenci un zemāku plūsmas ātrumu Ao magnētiskās rezonanses izmeklējumos pieaugušajiem, kuriem bērnībā AoCo korig̣ēta, izmantojot IZA pretstatā AGG. PAGG gadījumā nepieciešama apjomīga Ao loka un descendējošās Ao izdalīšana, kas jaundzimušajam kritiskā stāvoklī var nebūt priekšrocība. Ķirurğisku taktiku parasti izvēlas operējošais ķirurgs, vadoties no Ao loka formas un izmēru individuālām īpatnībām. 


\section{SECINĀJUMI}

1. Aortas koarktācijas prevalence jaundzimušajiem un zīdaiņiem Latvijā no 2000. līdz 2010. gadam ir 3,4 $\pm 1,3$ no 10000 dzīvi dzimušajiem.

2. Kumulatīva dzīvildze agrīna vecuma bērniem ar izolētu aortas koarktāciju būtiski pārsniedz dzīvildzi pacientiem ar koarktāciju un pavadošu intrakardiālu patolog̣iju $(p=0,001)$.

3. Ehokardiogrāfiskā atrade agrīna vecuma bērniem ar aortas koarktāciju liecina par infantilas aortas koarktācijas prevalenci ar variablas pakāpes aortas loka hipoplāziju.

4. Vēdera aortas pulsa viḷna doplerogrāfiski plūsmas mērījumi sniedz papildu informāciju par aortas loka obstrukciju.

5. Aortas koarktācija uzskatāma par komplicētu kardiovaskulāru sindromu ar nepieciešamību novēroties visu mūžu, jo izolētas koarktācijas gadījumā vērojama salīdzinoši laba īslaicīga prognoze ar multiplu komplikāciju attīstības iespēju ilgtermiņā (aortas rekoarktācija, arteriāla hipertensija, aortas aneirismas veidošanās).

6. No biomehānisko īpašību viedokḷa natīvai aortai vistuvākā ir anastomoze ar kreisās zematslēgas artērijas lēveru, kam seko pagarināta anastomoze galsgalā, anastomozes gals-galā gadījumā aorta ir visstingākā, kas var būt par cēloni hemodinamikas traucējumiem.

7. Ķirurǵiska ārstēšana ir pamatmetode aortas koarktācijas korekcijai jaundzimušajiem un zīdaiņiem, par izvēles metodi pieņemot pagarinātu anastomozi gals-galā, bet ielāps ar zematslēgas artērijas lēveru joprojām ir izmantojama metode gadījumos, kad citādi aortas loka rekonstrukcija nav iespējama bērniem ar mazu svaru un kritiski slimiem bērniem. Ielāps ar kreisās zematslēgas artērijas lēveru nerada būtiskus kreisās augšējās ekstremitātes funkcionālus traucējumus vidēji ilgā novērojumu periodā. 


\section{PRAKTISKI IETEIKUMI}

1. Nepieciešams uzsākt jaundzimušo arteriāla vada atkarīgu iedzimtu sirdskaišu skrīningu ar pulsoksimetriju pirms izrakstīšanās no dzemdību iestādes un izstrādāt detalizētas vadlīnijas ǵimenes ārstiem un pediatriem jaundzimušā pilnvērtīgai klīniskai kardiovaskulārā stāvokḷa novērtēšanai pēc izrakstīšanas no dzemdību iestādes, ietverot femorālā pulsa palpāciju katrā izmeklēšanas reizē.

2. Pacientiem pēc aortas koarktācijas ķirurǵiskas ārstēšanas jaundzimušāa un zīdaiṇa vecumā nepieciešama regulāra, sistemātiska ambulatora novērošana pie bērnu kardiologa, ietverot klīnisku un detalizētu ehokardiogrāfisku izmeklēšanu, veicinot savlaicīgu komplikāciju diagnosticēšanu (2.11. attēls - algoritms pacienta ar AoCo ārstēšanai/novērošanai).

3. Pulsa viḷna doplerogrāfiski plūsmas mērījumi vēdera aortā iekḷaujami rutīnas izmeklēšanas protokolā, novērojot pacientus pēc aortas koarktācijas korekcijas, lai laikus atpazītu rekoarktāciju. 


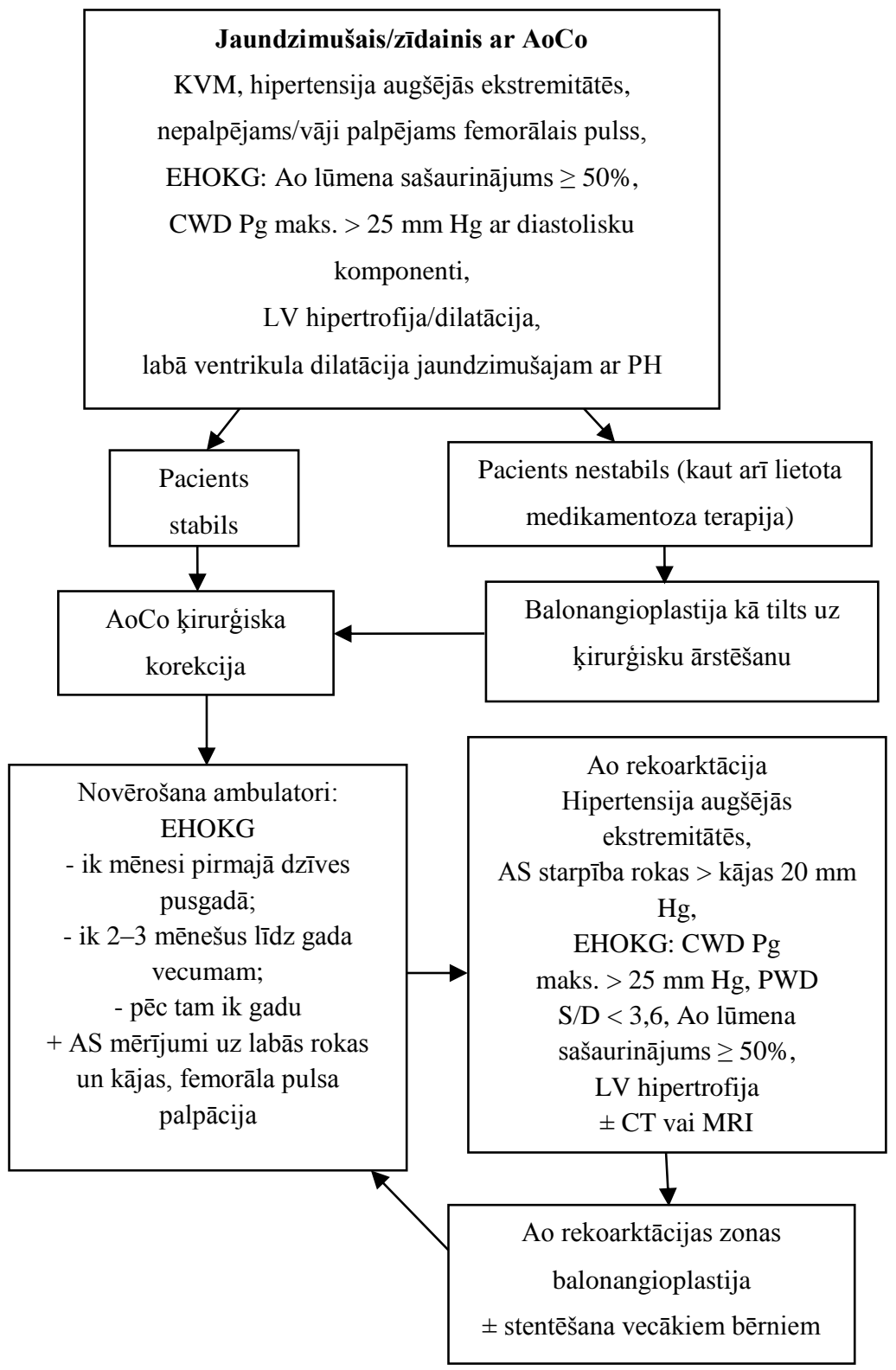

2.11. att. Algoritms pacienta ar AoCo ārstēšanai/novērošanai 


\section{PUBLIKĀCIJAS UN ZIN̦OJUMI PAR PĒTĪJUMA TĒMU}

\section{Publikācijas (zinātniskie raksti) par pētījuma tēmu}

1. Teivane E., Sikora N., Ozolins V., Smits L., Bergmane I., Lacis A., Kasyanov V. Biomechanical Properties of the Aorta in Neonates and Infants. Riga Stradins University Collection of Scientific Papers 2010; 6065.

2. Ligere E., Sikora N., Ozolins V., Smits L., Bergmane I., Lacis A., Kasyanov V. Biomechanical Properties of the Aorta in Neonates and Infants // Öchsner A. et al. (Eds.) Analysis and design of Biological Materials and Structures, Advanced Structured Materials 14, 125-132. DOI 10.1007/987-3-642-22131-6_10. Springer-Verlag, Berlin, Heidelberg, 2012.

3. Ligere E., Lacis A., Smits L., Ozolins V., Sikora N., Bergmane I., Lubaua I., Lace I., Feldmane L. Aortic coarctation repaired within the first year of life: an 11 year review. Acta Chirurgica Latviensis 2011 (11), 98-103. DOI 10.2478/v10163-012-0019-3.

4. Ligere E., Lacis A., Smits L., Ozolins V., Sikora N., Bergmane I., Lubaua I., Lace I. Timely and late recognition of the coarctation of the aorta in neonates and small infants. Riga Stradins University Collection of Scientific Papers, 2011; 54-60.

5. Ligere E., Ozolins V., Smits L., Sikora N., Melderis I., Feldmane L., Lacis A., Kasyanov V. The Biomechanical Properties of the Different Modalities of Surgically Corrected Coarctation of the Aorta in Neonates and Infants. World Academy of Science, Engineering and Technology Issue 66, June 2012; 60-63. pISSN 2010-376x, eISSN 2010-3778.

6. Ligere E., Lubaua I., Lace I., Bergmane I., Knauere V., Ozolins V., Smits L., Sikora N., Lacis A. Echocardiographic Follow up after Surgical Correction 
of the Aortic Coarctation within the First Year of Life in Latvia. (Pienemts publicēšanai žurnālā Proccedings of the Latvian Academy of Sciences Section B.)

\section{Konferenču tēzes par pētījuma tēmu}

1. Teivane E., Lacis A., Ozolins V., Smits L., Sikora N., Bergmane I. Surgical treatment of aortic coarctation within the first year of life: a 10 year review (clinical, surgical, biomechanical aspects). 44th Annual Meeting of the Association for European Paediatric Cardiology, AEPC with joint sessions with the Japanese Society of Pediatric Cardiology and Cardiac Surgery, Cardiology in the Young. Volume 20, Supplement 2, p71. Tēzes, stenda referāts, Innsbruka, Austrija, 26.-29. maijs, 2010.

2. Teivāne E., Sikora N., Ozoliņš V., Šmits L., Bergmane I., Lācis A., Kasjanovs V. Aortas biomehāniskās īpašības jaundzimušajiem un zīdaiņiem. RSU 2010. gada zinātniskā konference 18.-19. marts, 2010. Tēzes, stenda referāts.

3. Teivane E., Sikora N., Ozolins V., Smits L., Bergmane I., Lacis A., Kasyanovs V. Biomechanical Properties of the Aorta in neonates and Infants. 4th International Conference on Advanced Computational Engineering and Experimenting. Tēzes, stenda referāts, Parīze, Francija, 8.9. jūlijs, 2010.

4. Ligere E., Lācis A., Šmits L., Ozoliņš V., Sikora N., Lubaua I., Lāce I., Bergmane I. Aortas koarktācija jaundzimušajiem un zīdaiņiem. RSU 2011. gada zinātniskā konference 14.-15. aprīlis, 2011. Tēzes, stenda referāts. 
5. Ligere E., Lacis A., Smits L., Ozolins V., Sikora N., Bergmane I., Lubaua I., Lace I. The recognition of Coarctation of the Aorta in Neonates and Small Infants and its Relation to the Course of the Disease and the Outcomes. 45th Annual Meeting of the Association for European Paediatric Cardiology, AEPC with joint sessions with the Japanese Society of Pediatric Cardiology and Cardiac Surgery, Cardiology in the Young. Volume 21, Supplement 1, p122. Tēzes, stenda referāts, Granāda, Spānija, 18.-21. maijs, 2011.

6. Ozolinšs V., Šmits L., Sikora N., Bergmane I., Teivāne E., Lācis A. Aortas rekoarktācijas balondilatācija agrīna vecuma bērniem. RSU 2009. gada zinātniskā konference 2.-3. aprīlis, 2009. Tēzes.

\section{Ziṇojumi kongresos un konferencēs}

1. Teivāne E. Neinvazīvas izmeklēšanas metodes bērnu kardiologijāā. BKUS klīniskā konference, 12. decembris, 2008.

2. Teivāne E. Aktualitātes bērnu kardiolog̣ijā. Latvijas Pediatru asociācijas reǵionālais seminārs Daugavpilī, 30. oktobris, 2009.

3. Teivāne E. Aortas koarktācija jaundzimušajiem un zīdaiņiem. BKUS klīniskā konference, 10. decembris, 2009.

4. Teivāne E., Lācis A., Lubaua I., Šmits L., Ozoliņš V., Sikora N., Bergmane I., Lāce I. Ārstēšanas un izmeklēšanas iespējas un perspektīvas BKUS Bērnu kardiologijijas un kardioķirurğijas klīnikā. BKUS 1. starpdisciplinārā konference, 1. oktobris, 2009.

5. Lāce I., Ligere E. Arteriāla hipertensija un aortas koarktācija kā viens no iemesliem bērniem. Latvijas sporta medicīnas asociācija, Rīga, 19. maijs, 2011. 
6. Ligere E. Aortas koarktācija kā PDA atkarīga sirdskaite jaundzimušajiem un zīdaiṇiem. Bērnu kardiolog̣ijas asociācijas sēde, 8. aprīlis, 2011.

7. Ligere E., Lubaua I., Lāce I., Lācis A., Kasjanovs V. Ehokardiogrāfisks jaundzimušo un zīdaiņu aortas koarktācijas novērtējums. RSU 2012. gada zinātniskā konference, 29.-30. marts, 2012.

8. Ligere E. Aortas loka ehokardiogrāfisks novērtējums un aortas koarktācija bērniem. Latvijas Kardiologijas Biedrības Ehokardiogrāfijas darba grupas sēde, 11. maijs, 2012.

9. Ozolins V., Ligere E., Lacis A., Smits L., Lubaua I. Surgical Outcome after Correction of the Aortic Coarctation in Neonates and Infants. Mutisks referāts. The 12th Conference of the Baltic Association of Paediatric Surgeons, Rīga, 17.-19. maijs, 2012.

10. Ligere E., Ozolins V., Smits L., Sikora N., Melderis I., Feldmane L., Lacis A., Kasyanovs V. The Biomechanical Properties of the Different Modalities of Surgically Corrected Coarctation of the Aorta in Neonates and Infants. ICBBE 2012: International Conference on Biomechanics and Biomedical Engineering, Dānija, Kopenhāgena, 11.-12. jūnijs, 2012. 